\title{
Exosomes from glioma cells induce a tumor-like phenotype in mesenchymal stem cells by activating glycolysis
}

Zhanjun Ma' ${ }^{1}$ Xue Cui ${ }^{2}$, Li Lu ${ }^{4,5,6^{*}}$, Guohu Chen ${ }^{2}$, Yang Yang ${ }^{1}$, Yan $\mathrm{Hu}^{3}$, Yubao Lu' ${ }^{1}$, Zhangqi Xuexi Wang ${ }^{3,5,6^{*}}$

\section{Abstract}

Background: Exosomes are nanoscale membrane vesicles secreted by both normal an cell-derived exosomes play an important role in the cross-talk between cancer Is and oither cellular components in the tumor microenvironment. Mesenchymal stem cells (MSCs) have trop. tumor-tropic vectors for tumor therapy; however, the safety of such therapeut. vse of MSCs is unknown. In this study, we investigated the role of glioma cell-derived exosomes in th mor-like phenotype transformation of human bone marrow mesenchymal stem cells (hBMSCs) and explored the u, derlying molecular mechanisms.

Methods: The effect of exosomes from U251 glioma cells on the growt of hBMSCs was evaluated with the CCK-8 assay, KI67 staining, and a cell cycle distribution assessme t. Th igration and invasion of hBMSCs were evaluated with a Transwell assay. A proteomics and bioinformatics a transcriptase-polymerase chain reaction, was used to investig the effect of U251 cell-derived exosomes on the proteome of hBMSCs.

Results: U251 cell-derived exosomes induce a tumo kenotype in hBMSCs by enhancing their proliferation, migration, and invasion and altering the $\mathrm{R}$ oa tion of proteins involved in the regulation of the cell cycle. Moreover, U251 cell-derived exosomes promote MMP-9, glioma marker GFAP, and CS markers (CD133 and Nestin). The ten differentially expressed proteins identified participated in several bio vical processes and exhibited various molecular functions, mainly related to the inactivation of glycolysis. Western showed that U251 cell-derived exosomes upregulated the levels of Glut-1, HK-2, and PKM-2, leadir the induction of glucose consumption and generation of lactate and ATP. Treatment with 2-deoxy-D-glucdse significantly reversed these effects of U251 cell-derived exosomes on hBMSCs. Conclusions: Our $\mathrm{d}$ a $\mathrm{d} t \mathrm{f}$ honst ate that glioma cell-derived exosomes activate glycolysis in hBMSCs, resulting in their tumor-like phen e cumsformation. This suggests that interfering with the interaction between exosomes and hBMSCs in the tumy gicroenvironment has potential as a therapeutic approach for glioma.

Keywords: Exoso $\varsigma$ Glioma cells, Glycolytic pathway, Tumor-like phenotype transformation, Mesenchymal stem cells, Proteomics

* Corro Tndence: Iul@lzu.edu.cn; wangxuexi@|zu.edu.cn

Zhanjuh Ma and Xue Cui share first authorship.

Zhanjun Ma and Xue Cui contributed equally to this work.

${ }^{4}$ Institute of Pharmacology, School of Basic Medical Science, Lanzhou

University, Lanzhou 730000, Gansu, China

${ }^{3}$ School of Basic Medical Sciences, Lanzhou University, Lanzhou 730000,

Gansu, China

Full list of author information is available at the end of the article

(c) The Author(s). 2019 Open Access This article is distributed under the terms of the Creative Commons Attribution 4.0 International License (http://creativecommons.org/licenses/by/4.0/), which permits unrestricted use, distribution, and reproduction in any medium, provided you give appropriate credit to the original author(s) and the source, provide a link to the Creative Commons license, and indicate if changes were made. The Creative Commons Public Domain Dedication waiver (http://creativecommons.org/publicdomain/zero/1.0/) applies to the data made available in this article, unless otherwise stated. 


\section{Background}

Glioma is the most common malignant brain tumor in adults and is highly aggressive. Stem cell therapy is a new treatment option for glioma and has been evaluated in preclinical studies [1]. This approach involves the use of mesenchymal stem cells (MSCs), which can carry therapeutic factors and exert a potent anti-tumor effect [2], to alter the behavior of cancer cells.

Carcinogenesis is a multi-step, multi-factor regulatory process. Tumors consist of two principal structures: the parenchyma, or tumor cells, and the stroma, a supportive structure containing connective tissue, blood vessels [3], and macrophages, endothelial cells, lymphocytes, fibroblasts, and other mesenchymal cells. These stroma cells secrete hormones, cytokines, chemokines, and proteases to modulate the tumor microenvironment [4]. Tumor-associated stroma is a typical feature of neoplastic tissues and play a role in tumor growth, invasion, and metastasis by interacting with cancer cells [5].

MSCs are multipotent stem cells that can differentiate into stromal cells and are an important component of the tumor microenvironment. MSCs are found mainly in the connective tissue or interstitium and have marked self-renewal potential and the ability to differentiate into adipocytes, osteoblasts, and chondrocytes $[6,7]$. MSCs have low immunogenicity, immunomodulatory activity, and tropism for sites of injury and inflammation and ve potential for the treatment of various diseases inclu cancer [8]. These advantages have encoura ${ }_{5} 6$ investiga tions of MSCs as vehicles for the deliverv of an sancer agents [9]. However, Yu et al. [10] dem nstrated that $_{\text {MSCs }}$ promote the proliferation and invas $n$ of osteosarcoma cells in vitro. In addition, MSCs can pr te tamor angiogenesis and may directly differ inte into pericytes and contribute to the formation of mitu sculature, thereby promoting tumor progreos [11] Therefore, reports have indicated the importa of of interaction between MSCs and cancer cells.

Tumor cells influer e MSCs via secreted factormediated intercell communication. The microenvironment of the stem all niche is a key factor in stem cell homeos is 12 Changes in this microenvironment ma rad transformation of normal stem cells into alig ant cancer cells. For instance, Liu et al. [13] repu a trac exposure to the tumor microenvironment induce tumor-like phenotype in MSCs, an effect likely mediated by factors released by the cancer cells. Moreover, cancer-derived lysophosphatidic acid stimulated the differentiation of MSCs into myofibroblast-like cells [14]. In this regard, exosomes have a vital role in this activity. These results indicate the importance of the microenvironment on MSC behavior, although the underlying mechanisms are unclear. Whether changes in the characteristics of bone marrow mesenchymal stem cells in the glioma microenvironment are caused by exosomes also remains to be determined.

Exosomes are membrane-bound vesicles of $30-120 \mathrm{~nm}$ secreted by various cell types, including reticulocytes, stem cells, and dendritic cells, as well as tumor cells. Exosomes contain a large number of biologically active molecul ${ }^{\star}$ such as functional proteins, mRNAs, miRNAs, and ncPNAs. Exosomes play an important role in intercellular co nunication by mediating the exchange of substances and $r$ mation between cells, thereby affecting physi logical functions of cells $[15,16]$. Moreover exoson roportedly play an important role in regulatin the tumor nicroenvironment. Exosomes released by tui $r$ cells contain oncogenic molecules, which are in. tan cumor metastasis and progression, as well $r$ the tur $r$-like phenotype transformation of MSCs. I ic exosones released by cancer cells can be internatized YMSCs, leading to their transformation into ancer-associated fibroblasts [17-19]. In addition, lun. exposomes induce the proinflammatory a ity of MSCs, which promotes tumor survival [ ${ }^{2}$ owever, whether glioma exosomes regulate the tumor like phenotype transformation of MSCs is unknown.

- valuate the risk of human bone marrow mesenchynal s m cells (hBMSCs) undergoing tumor-like phenotype 4. sormation when used for biological therapies in the tunor microenvironment, we cultured exosomes produced by U251 cells with BMSCs. The U251-derived exosomes promoted cell proliferation, migration, and invasion and upregulated glioma-specific protein levels. A proteomic analysis indicated that U251 cell-derived exosomes induced a tumor-like phenotype in hBMSCs by activating glycolysis. These results will facilitate the clinical use of hBMSCs to treat gliomas.

\section{Materials and methods \\ Materials}

Dulbecco's modified Eagle's medium (DMEM)/F12 medium, fetal bovine serum (FBS), and antibiotics were purchased from Gibco/BRL (Gaithersburg, MD, USA). All reagents used for two-dimensional electrophoresis (2-DE) were obtained from Bio-Rad Laboratories (Milan, Italy), and silver staining kits were obtained from CWBIO (Beijing, China). Glucose and lactate assay kits were purchased from Nanjing Jiancheng Bioengineering Institute (Nanjing, China). The cell cycle analysis kit, Dil red fluorescence cell linker kit, and ATP assay kit were purchased from Beyotime Biotech (Nantong, China). Primary antibodies against Tsg101, CD133, Nestin, GFAP, PKLR, ANXA2, ENO1, Glut-1, HK-2, and PKM-2 were purchased from Cell Signaling Technology (Danvers, MA, USA). Antibodies against HSP70, CD9, MMP-2, MMP-9, PCNA, C-myc, and GAPDH were obtained from Proteintech Group Inc. (Chicago, IL, USA). The 
anti-TAGLN antibody was sourced from Abcam (UK). All other reagents were obtained from Sigma-Aldrich, unless otherwise indicated.

\section{Cell culture}

hBMSCs were purchased from ScienCell Research Laboratories (Carlsbad, CA, USA). Human glioma U251 cells were purchased from Cyagen Biology (Santa Clara, CA, USA). Both hBMSCs and U251 cells were cultured in DMEM/F12 medium supplemented with $10 \%$ FBS and $1 \%$ penicillin-streptomycin. hBMSCs were passaged to the fourth generation for experimentation. Cells were cultured in a humidified $37^{\circ} \mathrm{C}$ incubator with a $5 \% \mathrm{CO}_{2}$ atmosphere.

\section{Isolation and characterization of U251 cell-derived exosomes}

U251 cells were maintained in DMEM/F12 supplemented with 10\% exosome-depleted FBS (EXO-FBS-50A-1, System Bioscience, Mountain View, USA) for 48 h (80-90\% confluence), and the culture medium was collected and centrifuged at $800 \times g$ for $5 \mathrm{~min}$ and $1500 \times g$ for $15 \mathrm{~min}$ to remove supernumerary cells. Next, the supernatants were filtered using a Steriflip $(0.22 \mu \mathrm{m}$, Millex-GP; Millipore, Burlington, MA, USA), and the filtrates were concentrated in a $10-\mathrm{kDa}$ ultracentrifuge tube (Amicon Ultra 15; Millipore) at 40, $0 \times \mathrm{g}$ for $30 \mathrm{~min}$. U251 cell-derived exosomes were subse isolated using ExoQuick-TC ${ }^{\mathrm{m}}$ (System Bioscien ce, Mo tain View, CA, USA) according to the manufa a ar's direc tions. The mixture was refrigerated overnignt at ${ }^{\circ} \mathrm{C}$ and centrifuged at $1500 \times g$ for $30 \mathrm{~min}$, an the superiatants were aspirated. The exosome-cont ning pellets were suspended in phosphate-buffered sali (PBS) and used immediately or stored at -80 The protein density of exosomes was measured with a $\mathrm{B} \%$, otein micro-assay (CWBIO, Shanghai, Cb.m The size of exosomes was measured using a Zet. ver rnno series-Nano-ZS (Malvern Instruments, Worcesters $\ominus$, UK) according to the manufacturer's directio The ex some markers HSP70, Tsg101, and CD9 were de ted by Western blotting, and the surface prarkers CD6, and CD81 were detected by flow cytome

\section{ollul uptal.e of U251 cell-derived exosomes}

E. onics were labeled using a Dil red fluorescence cell linke. Kit according to the manufacturer's instructions. Purified exosomes were labeled with $1 \mu \mathrm{M}$ Dil solution for $15 \mathrm{~min}$ at $37^{\circ} \mathrm{C}$ and washed twice with PBS to remove excess Dil. hBMSCs (50\% confluence) were incubated with the Dil-labeled exosomes for $12 \mathrm{~h}$ in a humidified $37{ }^{\circ} \mathrm{C}$ incubator with a $5 \% \mathrm{CO}_{2}$ atmosphere. Next, the hBMSCs were fixed with $4 \%$ paraformaldehyde for $30 \mathrm{~min}$ at room temperature and washed twice with PBS, and the nuclei were counterstained with DAPI for
10 min. Cellular uptake of U251 cell-derived exosomes was visualized using a Nikon Eclipse 80i confocal fluorescence microscope.

\section{Cell viability assay}

Cell viability was assayed using the Cell Counting Kit-8 (CCK-8). hBMSCs $\left(8 \times 10^{3} /\right.$ well $)$ were incu ated in 96-well plates for $24 \mathrm{~h}$ at $37^{\circ} \mathrm{C}$. Next, the mea. was changed to $100 \mu \mathrm{L} \mathrm{DMEM} / \mathrm{F} 12$ medium containing -0 , 300 , or $600 \mu \mathrm{g} / \mathrm{mL}$ U251 cell-derived eג omes. 'Subsequently, the plates were incubated $10 \mathrm{24}$,, , or $72 \mathrm{~h}$; $100 \mu \mathrm{L}$ of fresh medium containi g $10 \mu \mathrm{L}$ of $\mathrm{CCK}-8$ solution was added per well; and th lates y ere incubated for $30 \mathrm{~min}$. The optical dens at $40.1 \mathrm{n}$ was measured using a microplate reade (Bio- $\Lambda$ Hercules, CA, USA).

\section{Cell cycle analysis}

hBMSCs were caltu. $d$ in $25 \mathrm{~cm}^{2}$ plates to $40-50 \%$ confluence; the cultur vas exchanged for fresh medium containing $0.01 \%$ and incubation for $24 \mathrm{~h}$, which synchronizins " Then, the culture medium was replaced for fresh mediun containing 150, 300, or $600 \mu \mathrm{g} / \mathrm{mL} \mathrm{U251}$ cell-derived exosomes, and the plates were incubated for 48. Next, the cells were harvested, washed twice with DBS, Id fixed in ice-cold $70 \%(v / v)$ ethanol overnight at 4 Sabsequently, the cells were washed with PBS, stained with $500 \mu \mathrm{L}$ of propidium iodide $(50 \mathrm{mg} / \mathrm{mL})$ in the dark for $30 \mathrm{~min}$ at room temperature, and analyzed by flow cytometry (Accuri C6; BD Biosciences).

\section{Wound healing assay}

hBMSCs were cultured in 6-well cell culture plates until $70-80 \%$ confluence, and a scratch wound was created in the cell monolayer using a $200-\mu \mathrm{L}$ pipette tip. The cells were washed twice with PBS; conditioned medium containing 150,300 , or $600 \mu \mathrm{g} / \mathrm{mL} \mathrm{U} 251$ cell-derived exosomes was added: and the plates were incubated for $48 \mathrm{~h}$. Images of wound healing were captured using an inverted microscope.

\section{Transwell assay}

Cell migration and invasion were evaluated using Matrigel-coated and noncoated 24-well Transwell chambers (24-well insert; pore size, $8 \mu \mathrm{m}$; Corning Costar), respectively. Briefly, hBMSCs $\left(5 \times 10^{4}\right)$ were added to the upper chamber of the Transwell. The hBMSCs were treated with serum-free conditioned medium containing 150, 300, or $600 \mu \mathrm{g} / \mathrm{mL} \mathrm{U} 251$ cell-derived exosomes; an equal volume of exosome-depleted serum-free medium was used as the control. Complete medium containing 10\% FBS (as a chemoattractant) was added to the lower chamber of the Transwell. After incubation for $48 \mathrm{~h}$, the cells in the upper chamber were removed using a cotton swab and the remaining cells were fixed in $4 \%$ paraformaldehyde. The 
transmigrated cells were stained with $0.1 \%$ crystal violet, rinsed twice with PBS, and enumerated using an upright light microscope (Nikon, Yokohama, Japan).

Two-dimensional gel electrophoresis and image analysis 2-DE was performed as described previously [21-23]. Briefly, after treatment with $300 \mu \mathrm{g} / \mathrm{mL} \mathrm{U} 251$ cell-derived exosomes for $48 \mathrm{~h}$, hBMSCs were harvested and lysed in $250 \mu \mathrm{L}$ of lysis buffer. Whole-cell lysates $(85 \mu \mathrm{g})$ were added to a 17-cm immobilized $\mathrm{pH}$ 3-10 nonlinear gradient strip (Bio-Rad Laboratories) and rehydrated in an Ettan IPG-phor isoelectric focusing system at $20^{\circ} \mathrm{C}$ and $30 \mathrm{~V}$ for $10 \mathrm{~h}$. Sample uptake into the strip was achieved at $20^{\circ} \mathrm{C}$ using the following settings: $250 \mathrm{~V}$ for $30 \mathrm{~min}, 1000 \mathrm{~V}$ for 1 $\mathrm{h}$, and $500 \mathrm{~V}$ for $10 \mathrm{~h}$. Next, the strips were incubated in equilibration buffer $(1 \%[w / v]$ dithiothreitol and $2.5 \%[w / v]$ iodoacetamide in $6 \mathrm{M}$ urea, $0.375 \mathrm{M}$ Tris- $\mathrm{HCl}[\mathrm{pH} 8.8$, $20 \%$ glycerol, and $2 \%$ sodium dodecyl sulfate [SDS]). Second-dimension separation was performed with $12 \%$ SDS-polyacrylamide gel electrophoresis (PAGE) in two steps at $10^{\circ} \mathrm{C}: 70 \mathrm{~V} /$ gel for $30 \mathrm{~min}$ and $300 \mathrm{~V} /$ gel until the bromophenol blue reached the bottom of the gel. The gels were stained using a silver staining kit, and spots were detected using a GS-800 calibrated densitometer (Bio-Rad Laboratories). The images were analyzed using PDQue $t^{\mathrm{TM}}$ 2-DE (ver. 8.0.1; Bio-Rad Laboratories). Protein spot were extracted from the 2-DE gels and identified in matrix-associated laser desorption/ionization-t he of flig mass spectrometry (MALDI-TOF/MS) as d $\mathrm{scn}_{4}$ previously [21-23].

\section{Bioinformatics analysis Interaction network} The protein-protein interaction $\mathrm{n} \sim \mathrm{k}$ was analyzed using the STRING databus er. 105 (http://string-db.org).

\section{Gene Ontology analysis}

We analyzed the biological process (BP), molecular function (MF), and cellular component (CC) categories of the identified proteins in Gene Ontology (GO), a stratified tree structure for the examination of the functions of genes and proteins. Next, the Database for Annotation, Visuali ation, and Integrated Discovery (DAVID) was used t classify over-represented GO terms, and its functional an ation clustering tool was used to cluster functionally relate notations into groups. Finally, DAVID was vlied to assign the identified proteins to the Kyoto Fricyclop in of Genes and Genomes (KEGG) pathways.

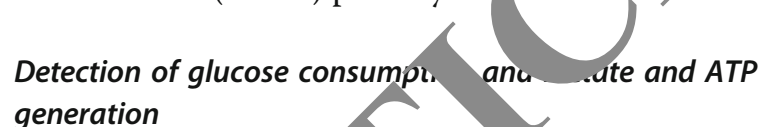

hBMSCs were seeder 4 -well plates with $200 \mu \mathrm{L}$ of medium per well. After in ation for $24 \mathrm{~h}$, the culture medium was exch ged for fresh medium containing 150, 300, or 60 251 cell-derived exosomes, and the plates were in bated for $48 \mathrm{~h}$. Subsequently, the supernatant cells were harvested, and the glucose and lactate levels in , ne medium were determined using glucose and lactate assay kits according to the manufactur instructions. Next, the hBMSCs were lysed, and the ly tes were purified by centrifugation at $15,000 \mathrm{rpm}$ a ${ }^{\circ} \mathrm{C}$ for $10 \mathrm{~min}$. The ATP concentration in the supernatants was measured using an ATP assay kit and a microplate reader (Bio-Rad Laboratories).

\section{Immunofluorescence and nuclear staining}

hBMSCs were seeded in 6-well plates and incubated with $300 \mu \mathrm{g} / \mathrm{mL}$ U251 cell-derived exosomes for $48 \mathrm{~h}$. The cultured cells were harvested and fixed in $4 \%$ paraformaldehyde for $10 \mathrm{~min}$ and washed three times with PBS. Then, the cells were permeabilized using a blocking solution $(5 \%$ bovine serum albumin) for $1 \mathrm{~h}$. Next, the cells were

\begin{tabular}{|c|c|c|}
\hline Gene & Forward primer sequence & Reverse primer sequence \\
\hline P21 & $\begin{array}{l}\text { GGATTGGTTGGTITGTTGG } \\
\text { AATTT }\end{array}$ & $\begin{array}{l}\text { ACAACCCTAATATACAACCAC } \\
\text { CCC }\end{array}$ \\
\hline P16 & AACGCACCGAATAGTTACGG & CACCAGCGTGTCCCAGGAAG \\
\hline & TATGGCTTCTGCCCTGAGAC & CACACCACATCTITCCGTCA \\
\hline & AGTCCACCCTTGTGCTCTTC & АСTCTCCACGCATCTCTGC \\
\hline & GATCAACTCACCGCCAACAG & AGGTTGTTCTCG GCTTCC AG \\
\hline CD133 & $\begin{array}{l}\text { ACAATTCACCAGCAACGAG } \\
\text { TCC }\end{array}$ & $\begin{array}{l}\text { GACGCTITGGTATAGAGTGCT } \\
\text { CA }\end{array}$ \\
\hline Nestin & GGG AGTCCGATGGGTTTG & GGC TCCCAACAGAAGACC \\
\hline Glut-1 & CाTGTGGCCTCTTGAAGT & CCACACAGTTGCTCCACAT \\
\hline PKM-2 & GGGTTCGGAGGTTTGATG & ACGGCGGTGGCTTCTGT \\
\hline HK-2 & TGCCAAGCGTCTCCATAA & GGTCAGCCAGACGGTAA \\
\hline GAPDH & GCACCGTCAAGGCTGAGAAC & ATGGTGGTGAAGACGCCAGT \\
\hline
\end{tabular}


incubated with anti-KI67 and anti-GFAP primary antibodies overnight at $4{ }^{\circ} \mathrm{C}$ in a dark room and detected using a FITC-conjugated secondary antibody. The nuclei were counterstained with DAPI for $10 \mathrm{~min}$, and the slides were washed three times in PBS and visualized under a fluorescence microscope (Olympus, Yokohama, Japan).

\section{Western blot analysis}

hBMSCs were harvested and lysed in RIPA lysis buffer (Beyotime Biotech). Subsequently, protein samples $(15 \mu \mathrm{g})$ were separated in a $12 \%$ SDS-PAGE gel, transferred to polyvinylidene difluoride (PVDF) membranes (Millipore), and blocked in Tris-buffered saline/Tween 20 solution containing 5\% nonfat dry milk for $2 \mathrm{~h}$ at room temperature. Next, the membranes were incubated with primary antibodies against MMP-2, MMP-9, PCNA, C-myc, CD133, Nestin, GFAP, PKLR, TAGLN, ANXA2, ENO1, Glut-1, HK-2, and PKM-2 at $4{ }^{\circ} \mathrm{C}$ overnight. Thereafter, the membranes were incubated with the corresponding secondary antibodies for $1 \mathrm{~h}$. Signals were visualized by chemiluminescence (Bio-Rad), and images of the blots were analyzed using ImageJ software (NIH, Bethesda, MD, USA).

The protein concentrations in U251 cell-derive exosomes were determined using a BCA protein ssav kit. Exosomal protein samples $(15 \mu \mathrm{g})$ were subjectec $12 \%$ SDS-PAGE and transferred to PVDF membranes. membranes were incubated with $\mathrm{Hs}_{\mathrm{N}}, \mathrm{CD}$, and Tsg101 primary antibodies and visuartzed ù o chemiluminescence substrate and gel i taging system (Image) software Bethesda, MD, USA)

\section{Quantitative reverse tranc ription antitative polymerase chain reaction}

Total RNA was isolated fro bBMSCs using IAzol lysis reagent (Qiager, $v$. encia, eA, USA) according to the

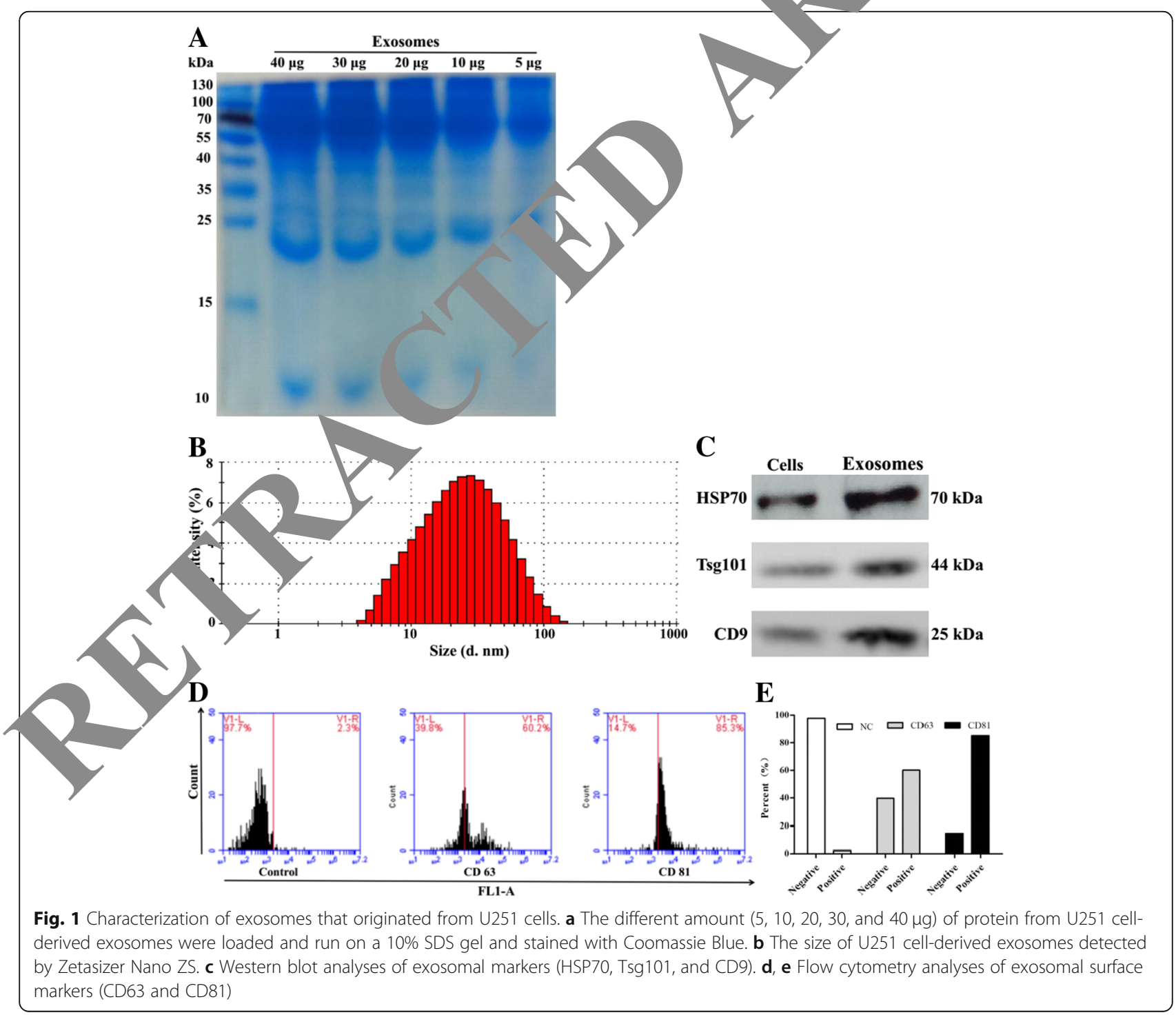




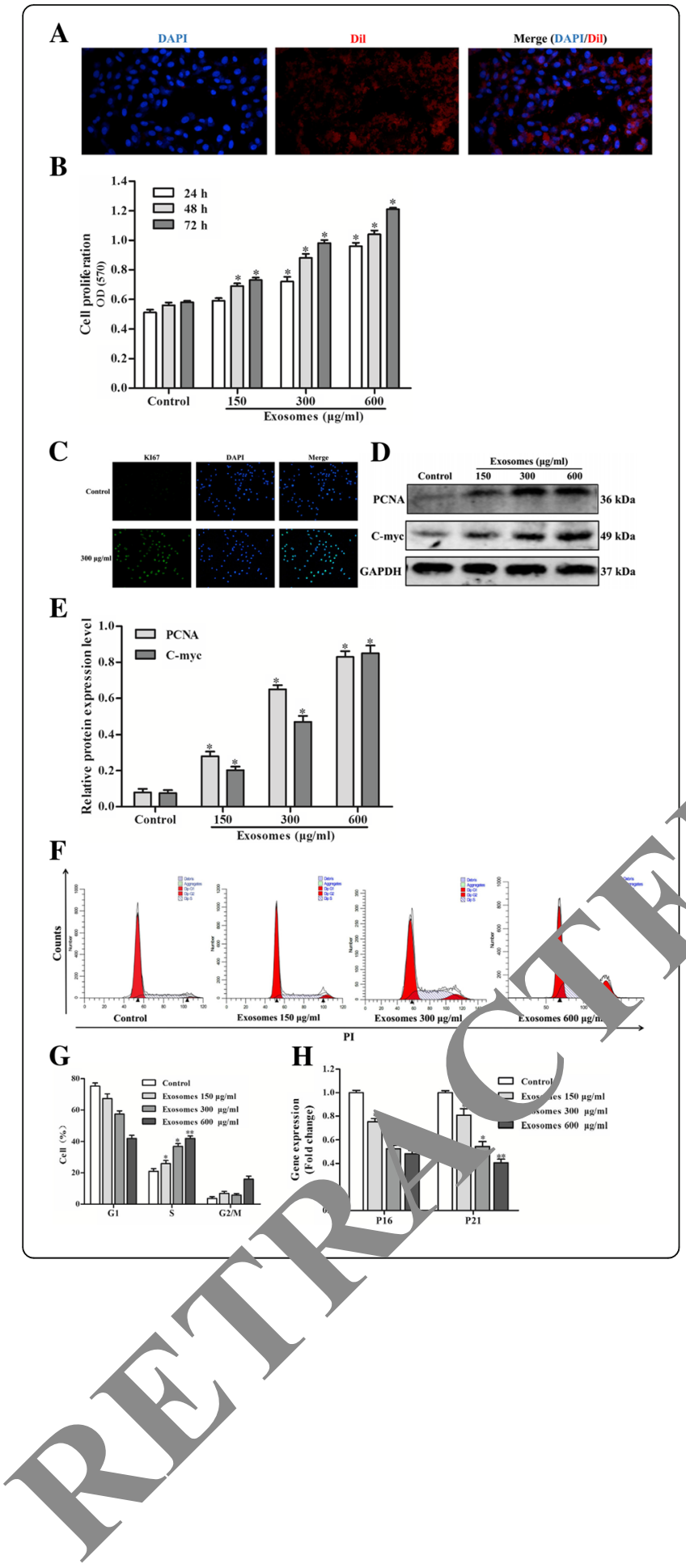

Fig. 2 U251 cell-exosomes promote the proliferation of hBMSCs. a Cellular internalization of Dil-labeled U251 cell-derived exosomes into hBMSCs. $\mathbf{b}$ hBMSCs were treated with different concentrations of U251 cell-derived exosomes for different time points $(24,48$, and $72 \mathrm{~h}$ ), and then cell viability was measured using the CCK-8 analyses. The results showed U251 cell-derived exosomes could promote hBMSC proliferation in a time- and dose-dependent manner vith respect to control cells $\left({ }^{*} P<0.05\right)$. c Representative image Kit $\mathrm{F}$ immunostaining in hBMSCs treated with or without U251 ce derived exosomes for $48 \mathrm{~h}$. Green fluorescence indigated the Kis positive cells. $\mathbf{d}$ Protein expression of PCNA and $/$ ve was determined by Western blotting analysis in hBMSCS ted U S 1 cell-derived exosomes for $48 \mathrm{~h}$. e Bar grap is showing th clative protein expression level of PCNA and C-r C in hBMSCs treated with U251 cell-derived exosomes for $48 \mathrm{~b}$ (The tein ley of $\mathrm{TAPDH}$ served as loading controls $\left({ }^{*} P<0.0\right.$. The s exposed with exosomes for $48 \mathrm{~h}$ showed an mcrease the $\mathrm{S}$ phase of the cell cycle compared to the con $\mathbf{g}$ Treatm $r$ of exosomes caused a $\mathrm{S}$ cell cycle arrest in a do e-dep tent manner, the arresting rate increased more rapid hBMSCS sed with exosomes than control cells for $4 \%$ h (*, 0.05, **P< 0.01 ). h Real-time PCR analysis of P21 and P16 on in hBMSCs treated with U251 cellderived exosomes to $\mathrm{R} h\left({ }^{*} P<0.05,{ }^{*} P<0.01\right)$

manufactule/s /nstructions. Complementary DNA (cDNA) was synthesized from $1 \mu \mathrm{g}$ of total RNA using a CD. reverse transcription kit (TaKaRA, Dalian, China) ccor ng to the manufacturer's instructions, and the $N$ A levels of p53, NS, GFAP, Glut-1, HK-2, PKM-2, PCNA, and C-myc were determined by RT-qPCR following a standard protocol with the LightCycler 96 System (Roche, Pleasanton, CA, USA) and detection via SYBR green (SYBR Green Supermix; TaKaRa). The results were normalized to the GAPDH mRNA level. Fold change values were analyzed using the $2^{-\Delta \Delta \mathrm{Ct}}$ method. The sequences of the primers are listed in Table 1.

\section{2-Deoxy-D-glucose treatment}

hBMSCs were treated with $300 \mu \mathrm{g} / \mathrm{mL}$ U251 cell-derived exosomes and $2.5 \mathrm{mM}$ 2-deoxy-D-glucose (2-DG) for $48 \mathrm{~h}$. To assess the proliferation, migration, invasion, and tumor-associated proteins of hBMSCs, the specific steps are the same as the above methods.

\section{Statistical analysis}

The data are presented as the means \pm standard deviation (SD) of triplicate experiments, and the statistical significance of differences was analyzed with Student's $t$ test using SPSS ver. 21.0 software (IBM, Armonk, NY, USA). A $P$ value $<0.05$ was considered to indicate statistical significance.

\section{Results}

Characterization of U251 cell-derived exosomes

To determine whether U251 cell-derived exosomes were successfully purified, firstly, the proteins acquired from U251 cell-derived exosomes were separated by $10 \%$ 


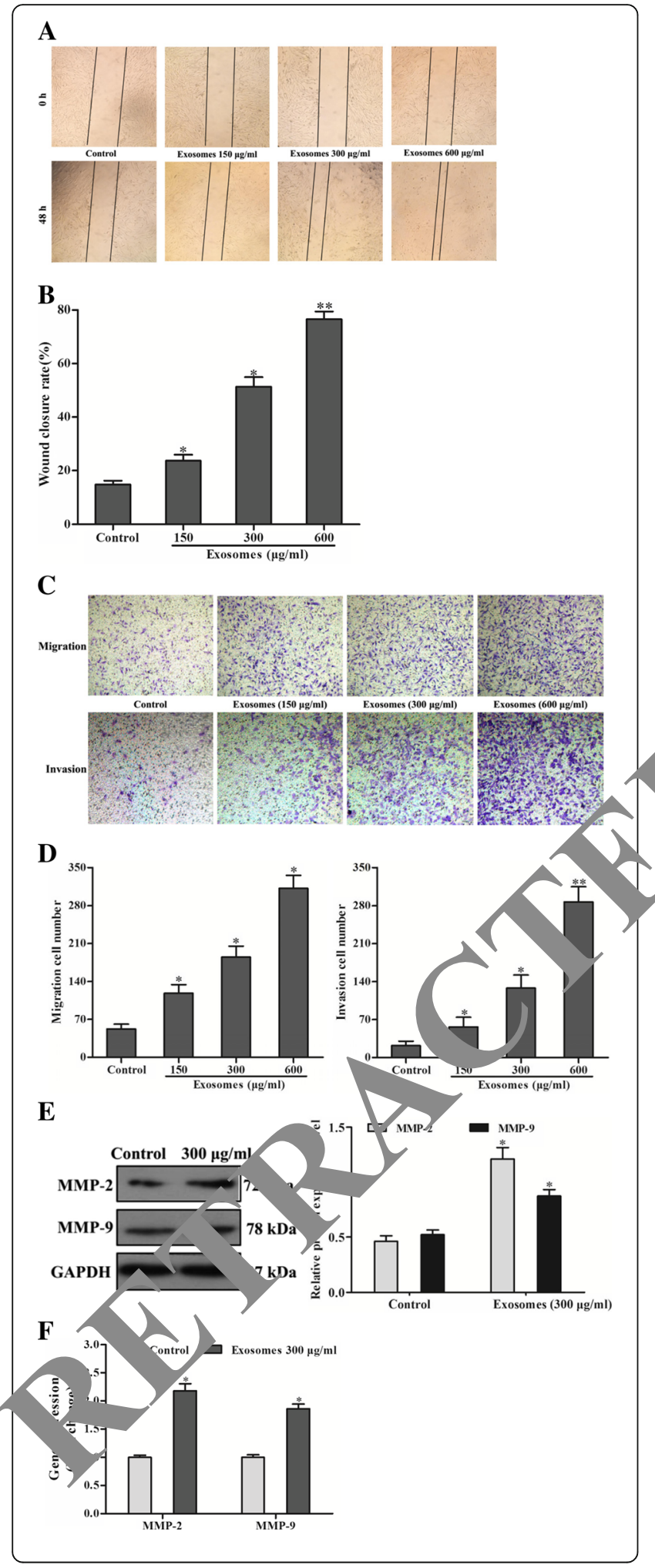

Fig. 3 U251 cell-derived exosomes contribute to the promotion of the migration and invasion of hBMSCs. a The movement of hBMSCs was observed by wound healing assay at $0 \mathrm{~h}$ and $48 \mathrm{~h}$ after exosomes treatment. $\mathbf{b}$ The wound closure rate of hBMSCs was quantified by measuring wound closure areas at $0 \mathrm{~h}$ and $48 \mathrm{~h}\left({ }^{*} P<\right.$ $\left.0.05,{ }^{* *} P<0.01\right)$. c The migration and invasion abilities of hBMSCs were examined by Transwell assay after treatment with U251 cellderived exosomes for $48 \mathrm{~h}$. The photos represented cell in ion into the underside of the Transwell membrane under a mich at $\times 200$ magnification field. $\mathbf{d}$ The hBMSC number that crossea Transwell chamber of each group was counted 2.1 veraged after treatment with U251 cell-derived exosomes ${ }^{\circ}$ or $40 \quad * P<0.05$, $\left.{ }^{*} P<0.01\right)$. e hBMSCs were treated with $300 \mu \mathrm{g} / \mathrm{mL}$ / cellderived exosomes for $48 \mathrm{~h}$. MMP-2 and MMP-9 prgteins in hBMSCs were detected by Westerr blo $\curlyvee$. The atios of MMP-2 and MMP-9 were relative to GAPL and udized to the control group ( $\left.{ }^{*} P<0.05\right)$. f The mRN, rpression levels of MMP2 and MMP-9 in hBMSCs, at with 51 cell-derived exosomes for $48 \mathrm{~h}\left({ }^{*} \mathrm{P}<\mathrm{P} .05\right)$

SDS-PAGE an with Coomassie Blue. The results indicated tha solated exosomes contained a large number $\mathrm{O}$ _. teins, which had an unlike profile (Fig. 1a). The exosones , ere 20-200 $\mathrm{nm}$ in diameter (Fig. 1b). Western blct analysis showed that the U251 cell-derived exu nes had higher levels of HSP70, Tsg101, and CD9 than J251 cells (Fig. 1c). Using flow cytometry, we no that the exosomes were positive for CD63 and Cb81 (Fig. 1d, e). Therefore, the vesicles isolated from the U251 cell culture supernatant were exosomes.

\section{Exosomes promote hBMSC proliferation}

After incubation with fluorescent-labeled exosomes for 12 $\mathrm{h}$, over $85 \%$ of the hBMSCs exhibited red fluorescence (Fig. 2a), indicating that the hBMSCs took up the U251 cell-derived exosomes. Moreover, the CCK-8 assay showed that the exosomes increased the proliferation of hBMSCs in a time- and concentration-dependent manner (Fig. 2b). In addition, Ki67 immunofluorescence staining demonstrated that exosomes significantly increased the proliferation of hBMSCs (Fig. 2c). Treatment with U251 cell-derived exosomes induced the production of PCNA and C-myc in hBMSCs (Fig. 2d, e). Flow cytometric analysis indicated that the proportion of exosome-treated hBMSCs in the $\mathrm{S}$ phase was greater than that of untreated hBMSCs (Fig. 2f, g). Using real-time PCR, treatment of hBMSCs with U251 cell-derived exosomes significantly downregulated p16 and p21 mRNA levels compared to the controls (Fig. 2h). Therefore, the U251 cell-derived exosomes accelerated DNA replication and promoted the proliferation of hBMSCs.

\section{U251 cell derived-exosomes promote the invasion and migration of hBMSCs}

The wound healing assay showed that treatment with U251 cell-derived exosomes significantly increased the 
wound closure rate of hBMSCs in a dose-dependent manner (Fig. 3a, b). Furthermore, the Transwell chamber assay showed that U251 cell-derived exosomes significantly increased the number of migrated and invaded hBMSCs compared to the control (Fig. 3c, d). Therefore, the U251 cell-derived exosomes increased the migration and invasion of hBMSCs in a dose-dependent manner.

Next, we evaluated the molecular mechanisms underlying the effect on hBMSC migration and invasion of U251 cellderived exosomes by Western blotting and real-time RTPCR. Exosome application increased MMP-2 and MMP-9 protein and mRNA levels (Fig. 3e-g). Therefore, the U251 cell-derived exosomes promoted the migration and invasion of hBMSCs by increasing the levels of MMP-2 and MMP-9.

\section{U251 cell-derived exosomes upregulate the protein levels of cancer markers}

CD133 and Nestin are markers of neural stem cely and cancer stem cells (CSCs), and GFAP is a marl of glioma cells. Via immunostaining, we found that thent with the exosomes induced GFAP expressio in hBMSCs (Fig. 4a). Western blot and $\nwarrow$ PCR a alyses showed that treatment of hBMSfes wit V 251 cellderived exosomes for $48 \mathrm{~h}$ upreg lated the protein and mRNA levels of GFAP, CD13 and Nestin in a dose-dependent manner $\mathbb{R}, 4 \mathrm{~b}$ Therefore, the

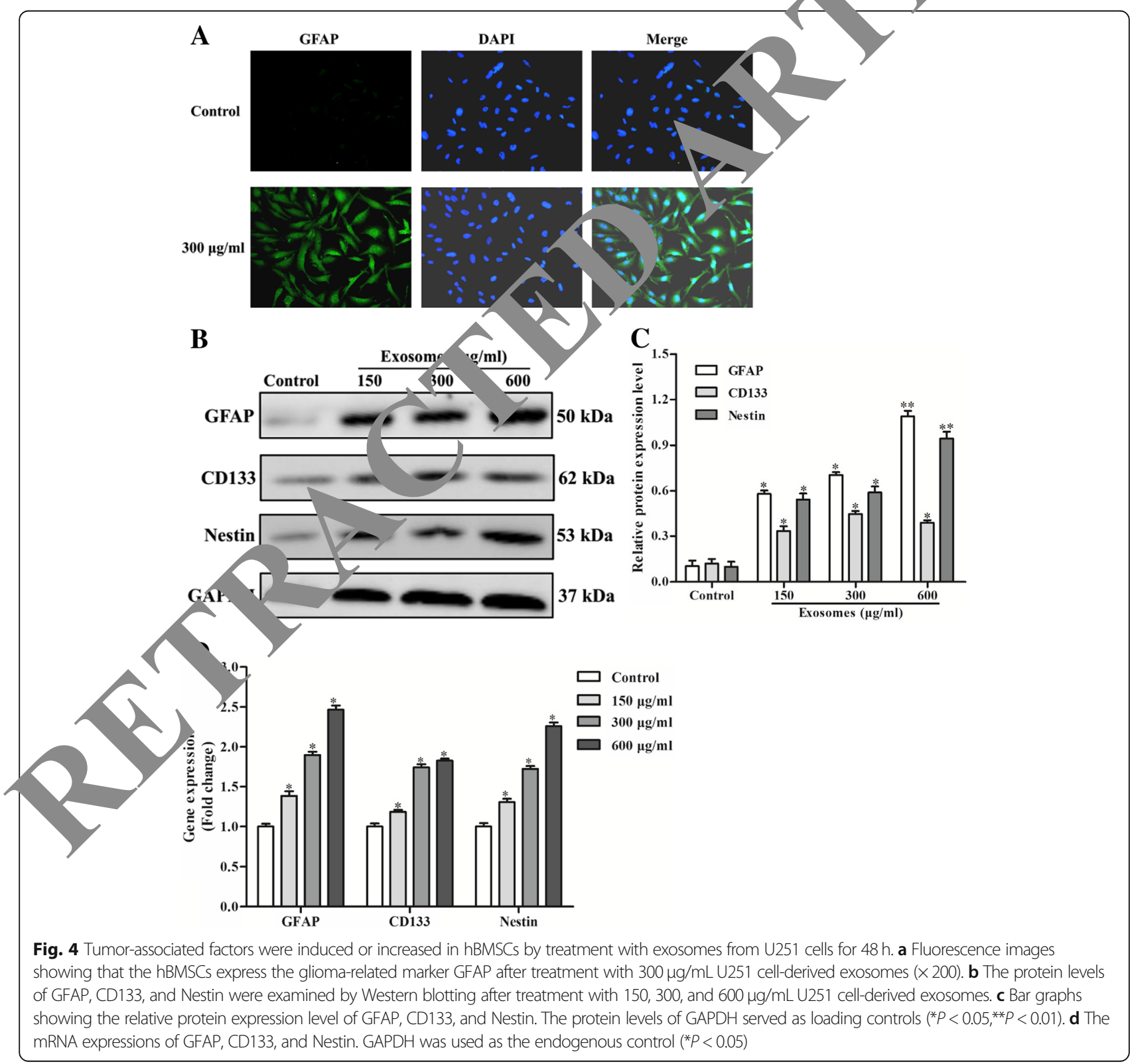



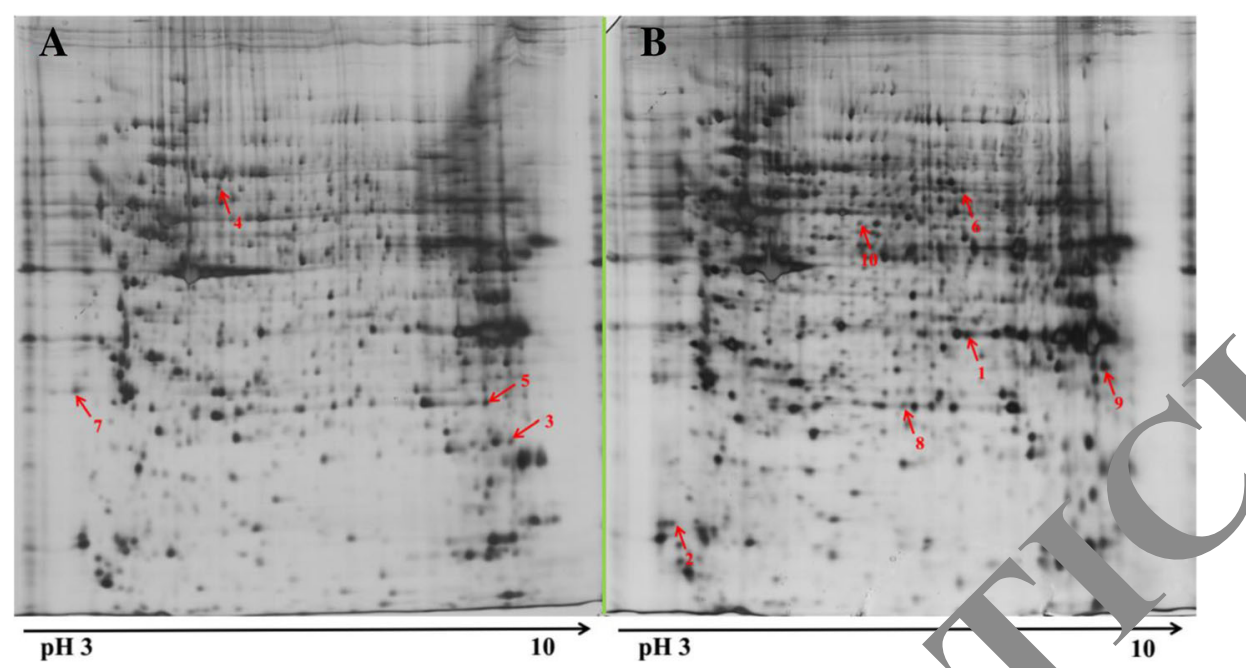

Fig. 5 2-DE profiling of the differentially expressed proteins between hBMSCs and hBMSCs incub with 300, $/ \mathrm{mL}$ U251 cell-derived exosomes for $48 \mathrm{~h}$. Total protein extracts were separated on pH 3-10 nonlinear IPG strips in th first mension, followed by 12\% SDS-PAGE in the second dimension and visualization by silver staining. a Representative 2-DE image of cont or 48 h. b Representative 2-DE image of hBMSCs treated with $300 \mu \mathrm{g} / \mathrm{mL}$ U251 cell-derived exosomes for $48 \mathrm{~h}$. The differentially expresse ots were identified by MS (marked with an arrow and number)

glioma microenvironment promotes the expression of GFAP, CD133, and Nestin, which may contribute to che tumor-like phenotype transformation of hBMSCs.

\section{Proteomics analysis}

Next, we performed a proteomics analysis of ht iSCs treated with $300 \mu \mathrm{g} / \mathrm{mL} \mathrm{U251} \mathrm{cell-d}$ ived exosomes for $48 \mathrm{~h}$. The resolution of proteins e acted from exosomes by 2D-PAGE generated meproducenc pairs of 2-D gel images (Fig. 5). The ten proter. twofold difference in in nsity between the exosomes and hBMSCs $\left(P<0.0^{\circ}\right.$ we $)$ used or further analysis.
Iden cation of proteins

the 15 protein spots, 10 were identified by M,, $\mathrm{LDI}-\mathrm{TOF} / \mathrm{MS}$ (Table 2). Among these 10 proteins,

(Annexin A2 [ANXA2], voltage-dependent anion-selective channel protein 1 [VDAC21], WD repeat-containing protein 1 [WDR1], phosphoglycerate kinase 1 [PGK1], enolase 1 [ENO1], and glucose-6-phosphate isomerase [GPI]) were upregulated and 4 (transgelin [TAGLN], pyruvate kinase [PKLR], triosephosphate isomerase [TPI1], and 14-3-3 protein zeta/delta [YWHAZ]) were downregulated. The search results for spots 1 and 5 are shown in Figs. 6 and 7 .

Table 2 MALD' TOC, S/MS identification results of differentially expressed protein spots

\begin{tabular}{|c|c|c|c|c|c|c|c|}
\hline Spot no. Procin name & Accession no. & MW (KD) & $\mathrm{pl}$ & Score & Sequence coverage (\%) & Matches & Expression change \\
\hline 1 & P07355 & 38.81 & 7.57 & 364 & 19 & $5(5)$ & Increase \\
\hline endent anion-selective channel & P21796 & 30.87 & 8.62 & 181 & 12 & $3(3)$ & Increase \\
\hline & Q01995 & 23.75 & 8.54 & 323 & 42 & $9(7)$ & Decrease \\
\hline Pyruvate kinase PKLR & P30613 & 61.83 & 5.82 & 392 & 31 & $12(9)$ & Decrease \\
\hline Triosephosphate isomerase & P60174 & 26.94 & 6.45 & 179 & 48 & $10(8)$ & Decrease \\
\hline WD repeat-containing protein 1 & O75083 & 66.82 & 6.17 & 254 & 52 & $7(6)$ & Increase \\
\hline 14-3-3 protein zeta/delta & P63104 & 27.90 & 4.73 & 182 & 31 & $6(4)$ & Decrease \\
\hline Phosphoglycerate kinase 1 & P00558 & 42.50 & 5.0 & 214 & 56 & $5(3)$ & Increase \\
\hline Enolase 1, (alpha) & P06733 & 47.59 & 6.44 & 273 & 21 & $8(5)$ & Increase \\
\hline Glucose-6-phosphate isomerase & P06744 & 59.13 & 6.40 & 135 & 44 & $6(5)$ & Increase \\
\hline
\end{tabular}




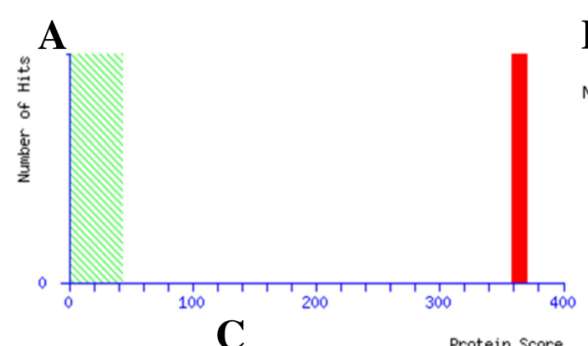

B

Matched peptides shown in bold red.

1 MSTVHEILCK LSLEGDHSTP PSAYGSVKAY TNFDAERDAL NIETAIKTKG 51 VDEVTIVNIL TNRSNAQRQD IAFAYQRRTK KELASALKSA LSGHLETVIL 101 GLLKTPAQYD ASELKASMKG LGTDEDSLIE IICSRTNQEL QEINRVYKEM 151 YKTDLEKDII SDTSGDFRKL MVALAKGRRA EDGSVIDYEL IDQDARDLYD 201 AGVKRKGTDV PKWISIMTER SVPHLOKVFD RYKSYSPYDM LESIRKEVKG 251 DLENAFLNLV OCIONKPLYF ADRLYDSMKG KGTRDKVLIR IMVSRSEVDM 301 LKIRSEFKRK YGKSLYYYIQ QDTKGDYQKA LLYLCGGDD
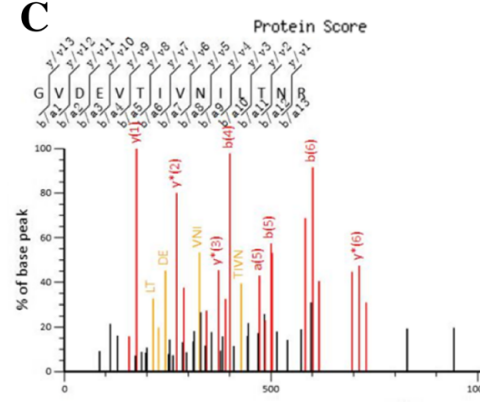

$\mathrm{m} / 2$

Fig. 6 Identification of protein spot \#1 from Fig. 5. a Output of the database searching by the gram using MS/MS data resulted in the identification of Annexin A2. b Protein sequence of Annexin A2 is shown. The matched peptia re in bold red. c Mass spectrum of tryptic peptide from spot \#1

\section{Confirmation of the protein identification by Western blot} analysis

The results of the Western blot analysis confirmed the differential levels of PKLR, TAGLN, ANXA2, and ENO1 in exosome-treated and exosome-untreated $\mathrm{hD} S \mathrm{SO}$ Treatment with the exosomes resulted in the upreg tion of ANXA2 and ENO1 protein and dom gulatio, of PKLR and TAGLN protein in hBMSCS ( $\left.\mathrm{F}_{l_{\mathrm{g}}} \mathrm{Q}, \mathrm{b}\right)$. The 2-DE and Western blot analy es yielded smilar results.

Bioinformati-s analysis of the signaling network

Ne. we used the online STRING database to predict the in eraction networks among the identified proteins 9a). ENO1, PKLR, and TPI1 were key nodes and modulators in the network. Next, the analysis of the GO function classifications of the proteins showed that 13 were annotated as MF, 97 as BP, and 23 as $C C(P<0.05)$. The top 10 significantly enriched GO terms identified by screening using a threshold false discovery rate of $<0.01$ are shown in Fig. 9b-d. In addition, the proteins were

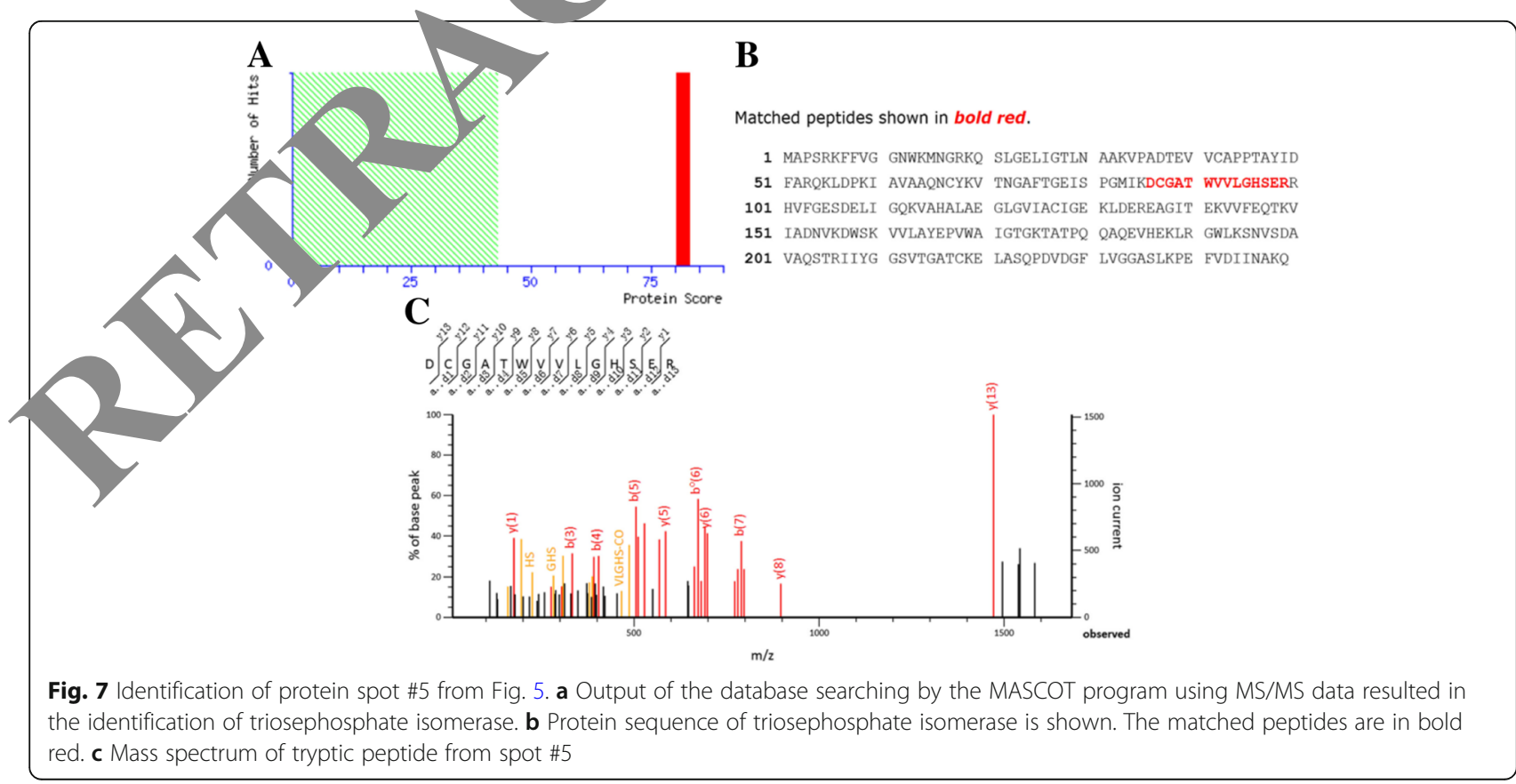



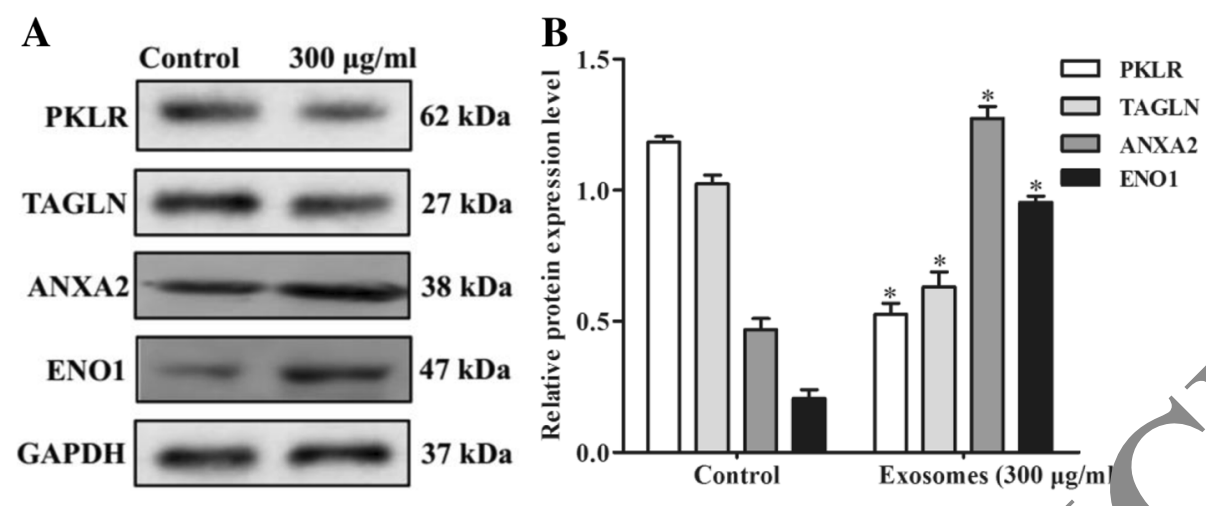

Fig. 8 Western blot analysis to confirm the PKLR, TAGLN, ANXA2, and ENO1 in hBMSCs treated with $300 \mu \mathrm{g} / \mathrm{mL} / 651 \mathrm{c}$ erived exosomes for $48 \mathrm{~h}$. a The PKLR, TAGLN, ANXA2, and ENO1 proteins in hBMSCs were detected by Western blotting. b Bar graphs wing ure relative expression levels of PKLR, TAGLN, ANXA2, and ENO1 proteins. GAPDH was used as internal control $(* P<0.05)$

enriched in the glycolysis/gluconeogenesis, carbon metabolism, biosynthesis of antibiotics, biosynthesis of amino acids, and metabolic KEGG pathways (Fig. 9e). The KEGG maps of the glycolysis/gluconeogenesis signaling pathways are shown in Fig. 9f. Therefore, the identified proteins were involved in several biological processes and showed diverse molecular functions, mainly related to the activation of the glycolysis/gluconeogenesis signaling pathway and other metabolic pathways.

U251 cell-derived exosomes activate glycolysis $; \mathrm{hBN}$. Changes in cellular metabolism are importan haractel istics of tumors, and aerobic glycolysis promotes e survival of tumor cells [23]. Therefore we explor d the effect of U251 cell-derived exosom on glycolysis in hBMSCs. Application of U251 cell-de d ex ssomes significantly increased the rate or "cose consumption, as well as those of lactate and ATI p/u,ction, in hBMSCs in a dose-dependent $\mathrm{m} r \mathrm{rig} 10 \mathrm{a}-\mathrm{c})$. Moreover, the protein and mRNA els f Glyt-1, HK-2, and PKM-2 were significantly upres ted by the U251 cell-derived exosomes in a ose-dep adent manner (Fig. 10d-f). Therefore, the U25, ell-derived exosomes modulated the glucose netabolism and enhanced the glycolysis in hBMSC

\section{hibi on of ylycolysis reverses tumor-like phenotype} tr. tormution of hBMSCs

To $v_{c}$ aate the finding that induction of glycolysis induces a tumor-like phenotype in hBMSCs, we used the glucose ana$\log 2$-DG, a competitive inhibitor of glycolysis. Treatment with $300 \mu \mathrm{g} / \mathrm{mL}$ U251 cell-derived exosomes promoted the proliferation, migration, and invasion of hBMSCs; these effects were reversed by 2-DG (Fig. 11a-c). Furthermore, Western blot analysis showed that MMP-2 and MMP-9 protein levels were decreased by 2-DG (Fig. 11d, e). Similarly, 2-DG decreased the exosome-mediated increased protein levels of PC A, C-myc, CD133, Nestin, and GFAP (Fig. 12a-c). Th abition of glycolysis reversed the tumor-like phenoty transformation of hBMSCs in the glioma micro monment.

\section{Discussion}

So umors comprise tumor cells, stromal cells, inflamnato cells, vasculature, and extracellular matrix, which ather form the tumor microenvironment [4]. Tumor derelopment, metastasis, and drug resistance depend on the communication between tumor cells and their microenvironment, which can be mediated by exosomes [24]. Exosomes promote tumor formation and development by mediating the intercellular transport of oncogenes and proteins. Cancer cell-derived exosomes may exert several effects simultaneously; therefore, their biological functions are somewhat unclear [25]. In this study, we focused on the role of exosomes in the tumor microenvironment.

Paracrine and endocrine signals cause MSCs to migrate toward the sites of wounds, injury, and inflammation. MSCs can also migrate to tumors, which may be considered to be "never-healing wounds" and comprise tumor stroma [26]. Therefore, MSCs show potential as vehicles for anti-cancer agents [27]. However, exosomes produced by tumor cells are capable of influencing MSCs [28, 29]. MSCs are reportedly intimately associated with tumor cells in the tumor microenvironment; indeed, co-culture with lung cancer A549 cells promoted the proliferation and migration of hBMSCs, likely by modulating the expression of genes related to the ERK signaling pathway [30]. Furthermore, C6 glioma-conditioned medium induced a tumor-like phenotype in MSCs, possibly in a manner involving the S100B/RAGE pathway [31]. The mechanisms by which cancer cells induce MSCs to differentiate into myofibroblasts differ according to the type of cancer $[32,33]$. Therefore, the interaction between MSCs 
A

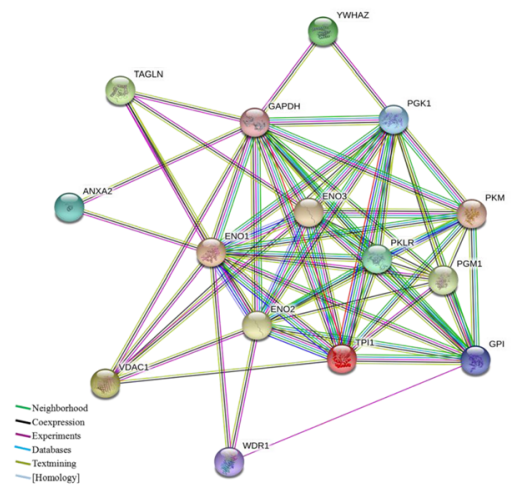

B

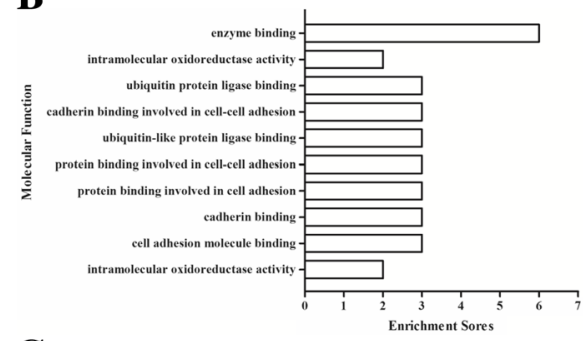

C
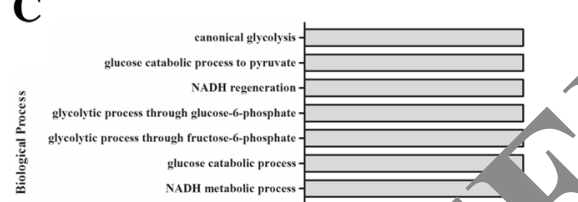

NADH metabolic proces

hexose catabolic proces:

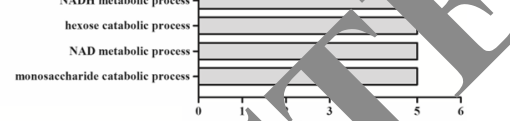

monosicecharide catabolic process

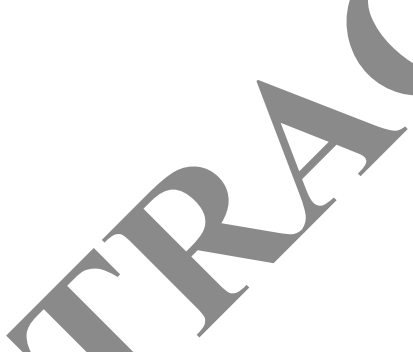

D

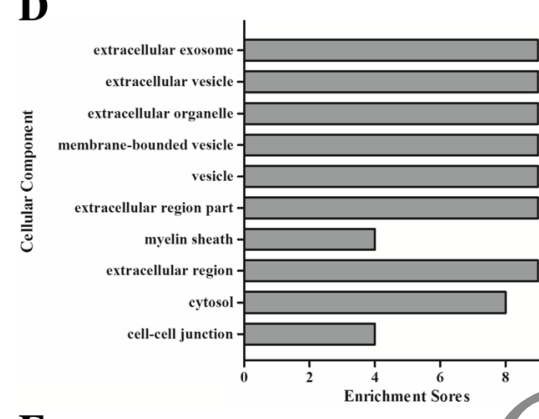

E
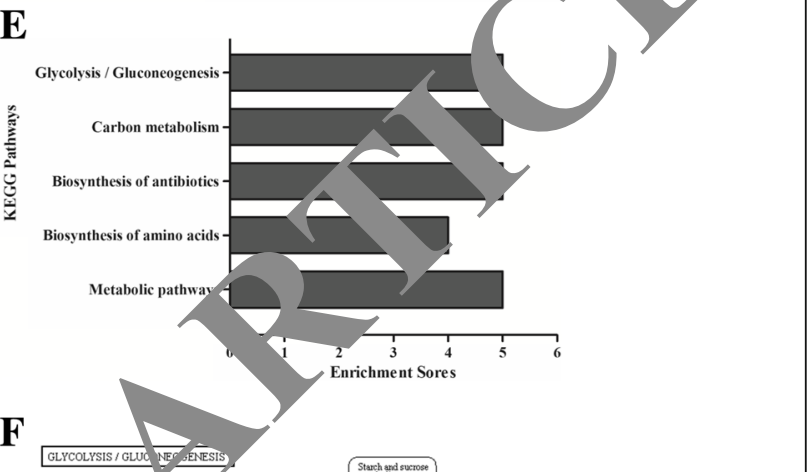

F

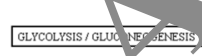

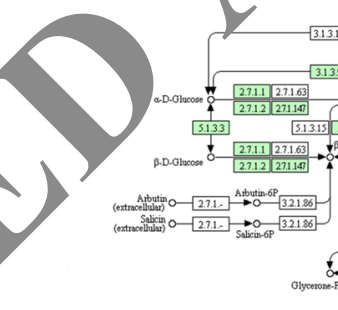

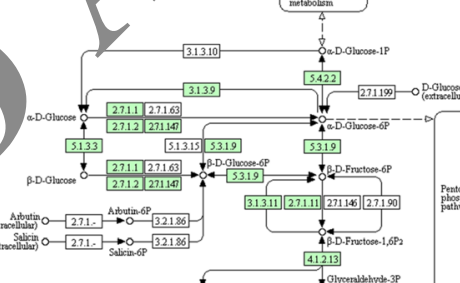

(extrocelithinitit)

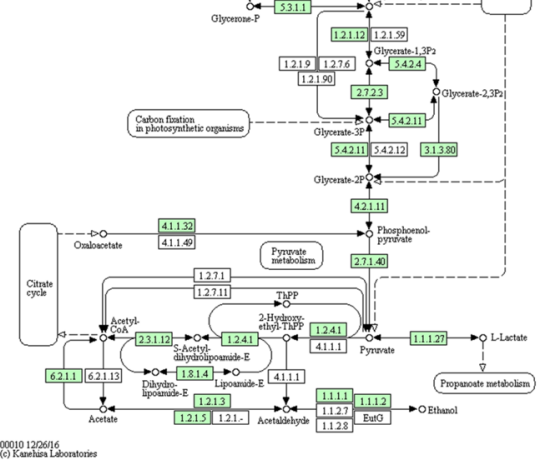

Fig. 9 Pr fein interaction, network and functional analysis. a The network containing ten identified differentially expressed proteins were mapped using $\mathrm{T}$ TR IG sy tem (http://string-db.org) based on evidence with different types. b-d Gene Ontology (GO) classification of the hBMSC protains at d by 251 cell-derived exosomes. The $y$-axis shows significantly enriched Gene Ontology (GO) terms relative to the genome, and the $\lambda$ kis shov the enrichment scores of these terms. b Molecular function (MF) categories in GO. c Biological process (BP) categories in GO. $\mathbf{d}$ vilu ponent (CC) categories in GO. e KEGG analysis of differentially expressed proteins associated signal pathways. $\mathbf{f}$ KEGG pathway e. hment analysis maps of the glycolysis/gluconeogenesis signal pathway

and tumor cells represents a candidate therapeutic target. Although MSCs undergo tumor-like phenotype transformation in the glioma microenvironment, the underlying mechanism is unclear. Therefore, we performed a proteomics analysis to clarify the effects of U251 cell-derived exosomes on hBMSCs, as well as the underlying mechanisms.
The U251 cell-derived exosomes were efficiently taken up by, and enhanced the proliferation of, hBMSCs. Moreover, the exosomes upregulated the protein levels of PCNA and C-myc in hBMSCs. PCNA is required for DNA replication and genome maintenance in actively growing cells. Due to its role in cancer cell proliferation, PCNA is widely used as a tumor marker. Abnormal 

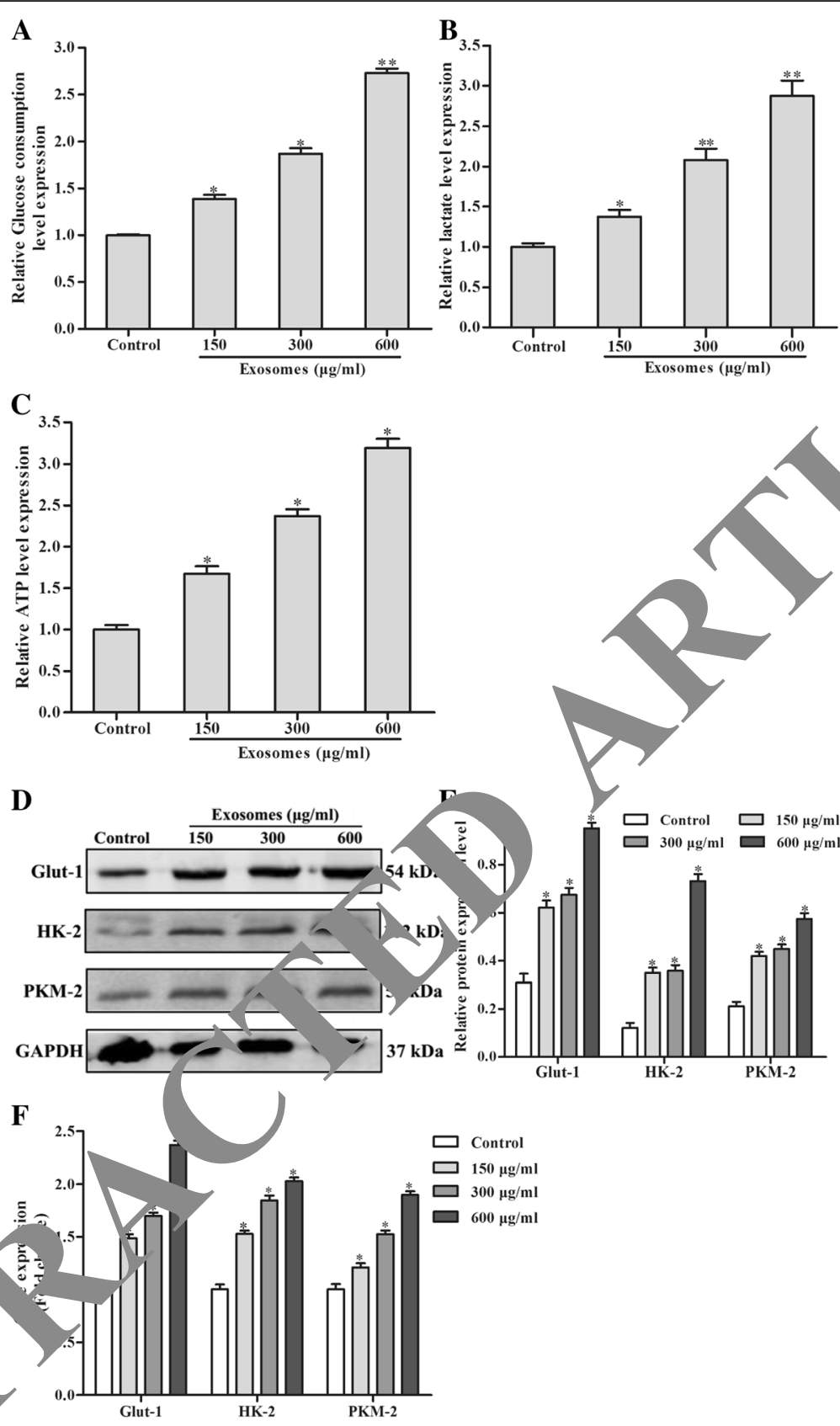

Fig. 10 If els df glycolysis pathway influenced by U251 cell-derived exosomes in hBMSCs. The hBMSCs were incubated with different concentrat $\quad(150,300$, and $600 \mathrm{\mu g} / \mathrm{mL})$ of U251 cell-derived exosomes for $48 \mathrm{~h}$. a-c The level of glucose consumption, lactate production, and cellu. ATP p uction were assayed. U251 cell-derived exosomes could increase the glucose consumption and lactate and ATP production mr $-1, H K-2$, and PKM-2) were measured by Western blotting after hBMSCs were treated with U251 cell-derived exosomes. e Bar graphs showing the Tive protein expression level of Glut-1, HK-2, and PKM-2. The protein levels of GAPDH served as loading controls $\left({ }^{*} P<0.05\right)$. $\mathbf{f}$ The $m R N A$ expressions of Glut-1, HK-2, and PKM-2. GAPDH was used as the endogenous control $(* P<0.05)$

expression of PCNA is closely related to the occurrence and development of tumors and can be used to evaluate their malignant and proliferative potential [34]. C-myc is a transcriptional regulator encoded by the proto-oncogene myc; C-myc at oncogenic levels reprograms cellular metabolism, as a marker of carcinogenesis, to maintain the high rate of proliferation of cancer cells [35]. Treatment with U251 cell-derived exosomes significantly increased the proportion of $S$ phase cells and downregulated the mRNA and protein levels of P16 and P21, negative regulators of the cell cycle in hBMSCs [36]. Therefore, the promotion by $\mathrm{U} 251$ cell-derived exosomes of the proliferation 


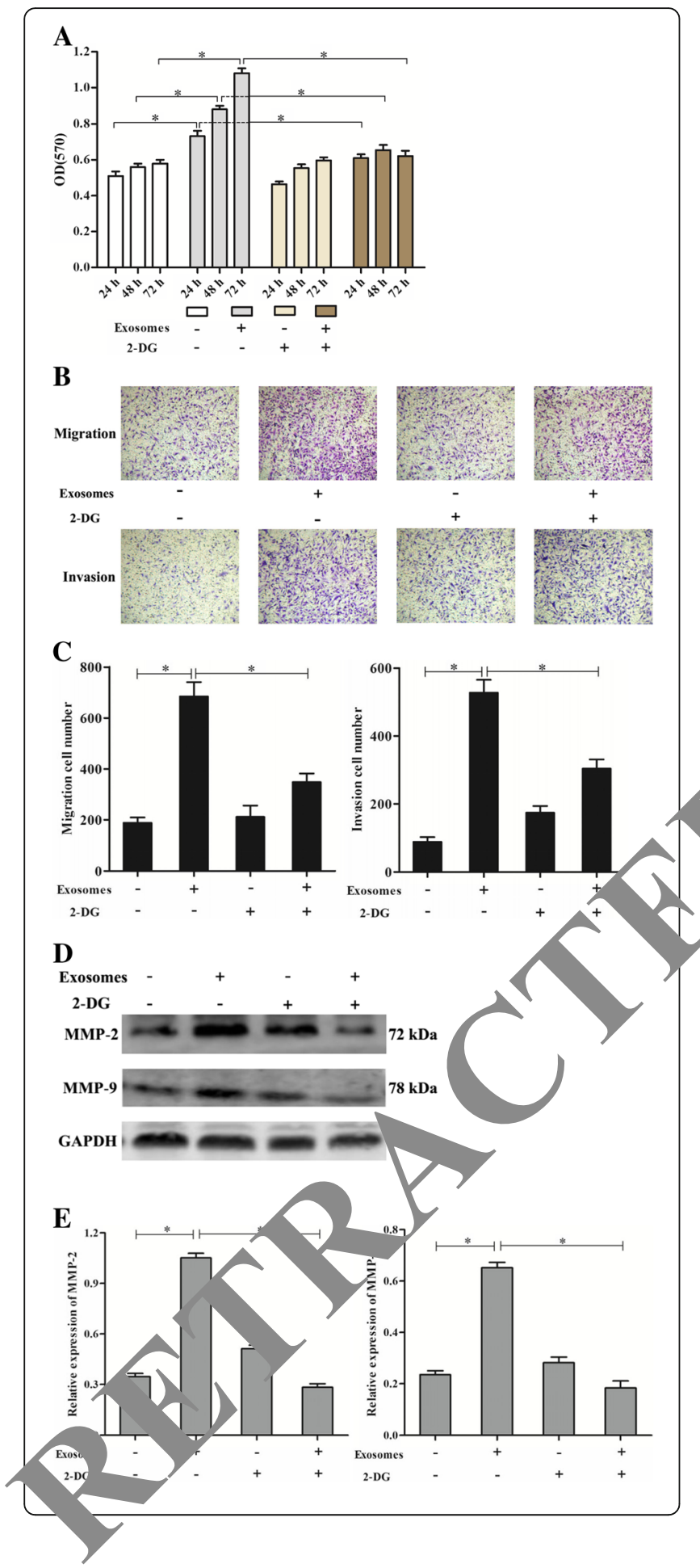

Fig. 11 2-DG reversed the tumor-like phenotype transformation of hBMSCs under the treatment of U251 cell-derived exosomes. The hBMSCs were incubated with $300 \mu \mathrm{g} / \mathrm{mL} \mathrm{U251}$ cell-derived exosomes or $2.5 \mathrm{mmol} / \mathrm{L} 2-\mathrm{DG}$ for $48 \mathrm{~h}$. a 2-DG could suppress the proliferation of hBMSCs under the treatment of U251 cellderived exosomes for $24 \mathrm{~h}, 48 \mathrm{~h}$, and $72 \mathrm{~h}\left({ }^{*} P<0.05\right)$. b, c The effects of 2-DG on hBMSCs migration capability were asseosea by the Transwell assay with or without Matrigel under treatment of U251 cell-derived exosomes. The number or migrated or invaded cells was quantified by counting the number of cells from five random fields at a $>$ magnilication $\left({ }^{*} P<0.05\right)$. d, e Protein levels of MMP-2 and MMr were examined by Western blotting under th treatment $/ 251$ cellderived exosome or $2.5 \mathrm{mmol} / \mathrm{L}$ 2-DG. APDH was an internal control $\left({ }^{*} P<0.05\right)$

of hBMSCs is linked to th ltered expression of C-myc and regulators of the cell cycle. $S_{\mathrm{H}}$ ifically, after incubation with Dil-labeled exosme it is found exosomes (or Dil) presented around $t$ (or DAPI) of hBMSCs, indicating that the hBMSCs in be take up the U251 cell-derived exosomes int cell nembrane or cytoplasm. Therefore, the specific cellyar 1 ,calization of exosomes-binding is still in need of furth or study.

found that the U251 cell-derived exosomes promoted the $\mathrm{m}$, gration and invasion of hBMSCs, possibly by modu1. 0 the expression of genes encoding matrix metalloproteinases (MMPs), which play an important role in tumor Invasion and metastasis [37]. The U251 cell-derived exosomes also upregulated the mRNA and protein levels of MMP-2 and MMP-9 in a dose-dependent manner. We also evaluated the mRNA and protein levels of GFAP, CD133, and Nestin by immunofluorescence, Western blotting, and RT-PCR. GFAP is known to be involved in normal astrocyte functions and commonly used as a histological marker for tumors of glial origin [38]. GFAP has been previously shown to be co-expressed with nestin in glioma cells and is over-expressed in the serum and peripheral blood of glioma patients in comparison with healthy controls; GFAP staining is considered a standard diagnostic marker for glioma [38]. Moreover, nestin is expressed in several types of cancer and it is strongly associated with glioma. Increased nestin expression has been related to higher grade glioma and lower patient survival rates [39]. Meanwhile, $\mathrm{CD} 133^{+}$human glioma cells can initiate tumor formation in the brains of immunodeficient mice. Interestingly, these cells also express nestin, indicating the possibility of CD133 expression on progenitor cells [40]. Some reports demonstrated that nestin and CD133 are markers of neural stem cells and are used to determine the biological properties of CSCs [41]. The U251 cell-derived exosomes upregulated the mRNA and protein levels of GFAP, CD133, and Nestin in hBMSCs, suggesting that hBMSCs undergo transformation into glioma CSCs in gliomas. Accumulating evidence indicates that tumors are derived from CSCs [42], which have self-renewal potential 


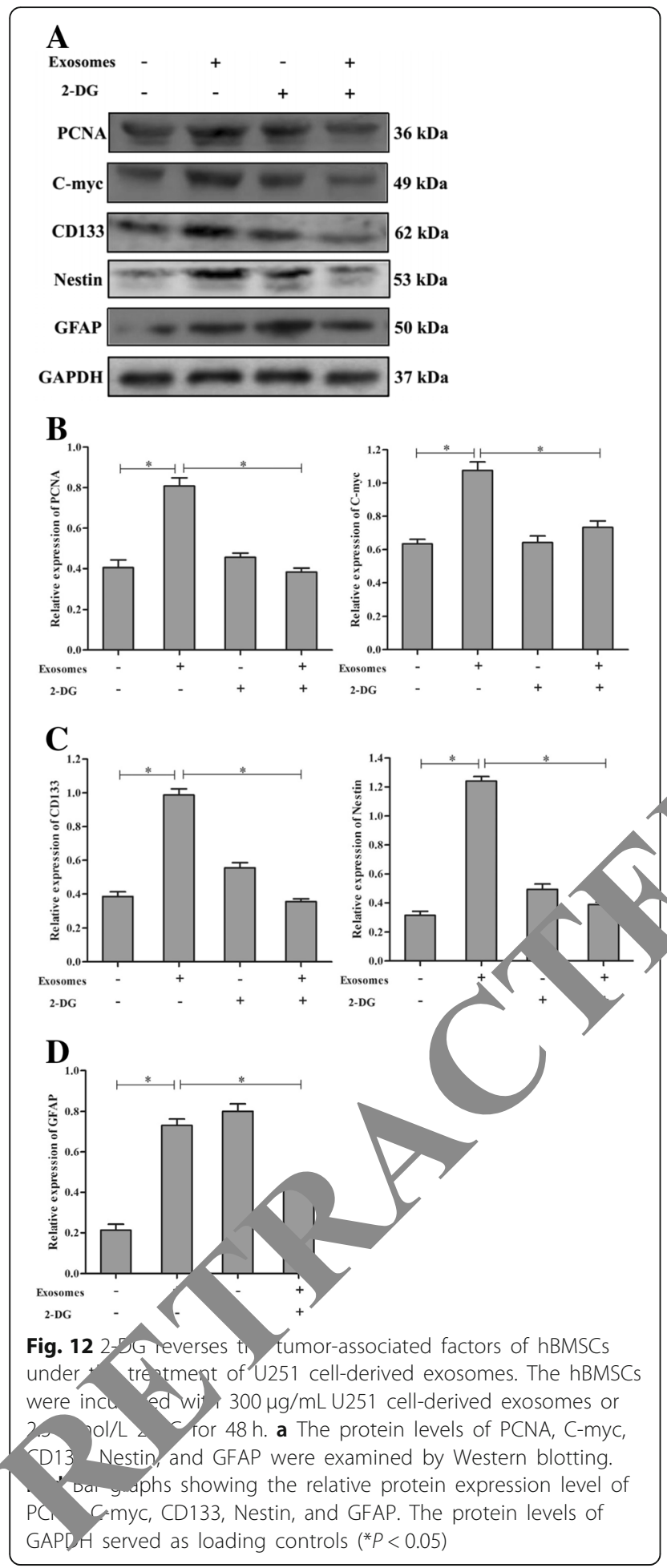

and enhanced proliferation, thereby promoting tumorigenesis [43].

We identified the target molecules of U251 cell-derived exosomes in hBMSCs by proteomics analysis; this yielded ten proteins whose levels differed between exosome-treated and exosome-untreated hBMSCs. Among them, six proteins (ANXA2, VDAC21, WDR1, PGK1, ENO1, and GPI) were upregulated and four (TAGLN, PKLR, TPI1, and YWHAZ) were downregulated. The PKLR, TAGLN, ANXA2, and ENO1 proteomics data were verified with Western blotting.

ENO1 encodes the enzyme responsible for the c nversion of 2-phosphoglycerate into phosphoenolpyr vate and c-myc binding protein (MBP-1) [44]. Overexpro on of ENO1 is related to tumor development, progression ad invasion. ENO1 promotes colorectal tu rigene is and metastasis through the AMPK/mTOR pathm ${ }^{2} 4 \%$ and is overexpressed in lung cancer ar promotes glycolysis, proliferation, metastasis, and norige esis through PI3K/AKT pathway activation 6]. roports support our finding that U251 cril-derivs exosomes significantly upregulated ENO1 in $\mathrm{AB}_{2}$ C Cs.

ANXA2 is a membrane und protein expressed in most eukaryoti $\mathrm{Ce}$, whose function is dependent on $\mathrm{Ca}^{2+}$ [47]. Alv ? a critical role in the adhesion, migration and in ion, proliferation, and angiogenesis of tumor [48]. ANAX2 is reportedly overexpressed in multiple cano,rs and is involved in their development and metasta is [49]. Therefore, the upregulation of ANXA2 ma, e related to the U251 cell-derived exosome-induced umo, like phenotype in hBMSCs.

GK1 is the first ATP-generating enzyme in glycolysis and catalyzes the reversible transfer of 1,3-bisphosphoglycerate and ADP into 3-phosphoglycerate and ATP [50]. PGK1 is secreted extracellularly by tumor cells, and its upregulation is associated with tumorigenesis [51-53]. PGK1 regulates glycolysis, angiogenesis, and autophagy, which play vital roles in cancer metabolism and tumorigenesis [53]. In this study, treatment with U251 cell-derived exosomes upregulated PGK1 in hBMSCs, suggesting the promotion of glycolysis leading to tumor-like phenotype transformation.

Among the 10 protein spots identified, 6 were upregulated and 4 were downregulated. These proteins clustered in an interaction network centered on ENO1, PKLR, GAPDH, and TPI1, which are related to glycolysis. Thirteen GO functional annotations of MF, 97 of BP, and 23 functional annotations of $\mathrm{CC}$ were significantly enriched in the identified proteins. The principal KEGG pathways of the identified proteins were glycolysis/gluconeogenesis, carbon metabolism, biosynthesis of antibiotics, biosynthesis of amino acids, and metabolic pathways; therefore, these pathways played a key role in the effect of U251 cell-derived exosomes on hBMSCs. The identified proteins were involved in diverse biological processes and exhibited several molecular functions, mainly related to the activation of glycolysis/gluconeogenesis and metabolic pathways.

Energy metabolism involves energy production, release, conversion, and utilization. Normal cells generate 
energy mainly by aerobic oxidation of glucose [54]. In the presence of sufficient oxygen, tumor cells use glycolysis to generate energy. Although glycolysis is inefficient, it can provide ATP and macromolecules to meet the energy and material needs of the rapidly proliferating tumor cells [55]. The Warburg effect involves the conversion of energy production by tumor cells from oxidative phosphorylation to glycolysis, which is a major feature of cancer [56]. Tumor development and metastasis are closely related to glycolysis, and MSCs play an important role in the metabolic reprogramming of cancer cells and their stroma $[57,58]$. Such abnormal metabolic reprogramming, particularly increased glycolysis, can induce the epithelial-mesenchymal transition in cancer cells and their acquisition of CSC-like properties, thereby promoting tumor progression [59].

Treatment with the U251 cell-derived exosomes resulted in the upregulation of Glut-1, HK-2, and PKM-2. This led to the increased glucose consumption and lactate and ATP generation, suggesting that U251 cell-derived exosomes enhanced the glucose metabolism of hBMSCs. Glut proteins transport glucose into cancer cells to supply the energy required for proliferation and differentiation via glycolysis or aerobic oxidation. Glut-1 is upregulated in a number of tumors and contributes to the Warburg effect [60]. HK-2 is the rate-limiting enzyme that catalyzes the first step of glycolysis, i.e., conversion of glucose into glucose-6-phosphat 61 ] PK catalyzes the final step of glycolysis, irreversible conversion of phosphoenolpyruvate into pyruvate, which is accompanied by ATP generation [62]. The PK isoform PKM-2 is commonly expressed in cancer cells and is involved in glycolysis, proliferation, and tumor-like phenotype transformation [63]. Treatment with the competitive inhibitor of gly lysis 2-DG reversed the effects of the U251 cel-derived exosomes on hBMSCs. In summary, inhib n of glycolysis may reverse the tumor-like phen pe transformation of hBMSCs in the rloma microenvironment.

\section{Conclusions}

Our findings suggest that gh na cell-derived exosomes induce a tum or phenotype in hBMSCs, as indicated by the increas proliferation, migration, and invasion, tha he expression of cancer markers. Proteomics an $y$ blot analyses showed that the exosome-in ced tumor-like phenotype in hBMSCs due to the activation of glycolysis. Therefore, gion, a cell-derived exosomes promote the growth, migration, and invasion, as well as induce the tur. like phenotype transformation, of hBMSCs by ctivà ng glycolysis (Fig. 13). Our findings suggest 4. exosomes activate MSCs in the tumor microenvironment, and the inhibition of this effect shows promise for the treatment of cancer.

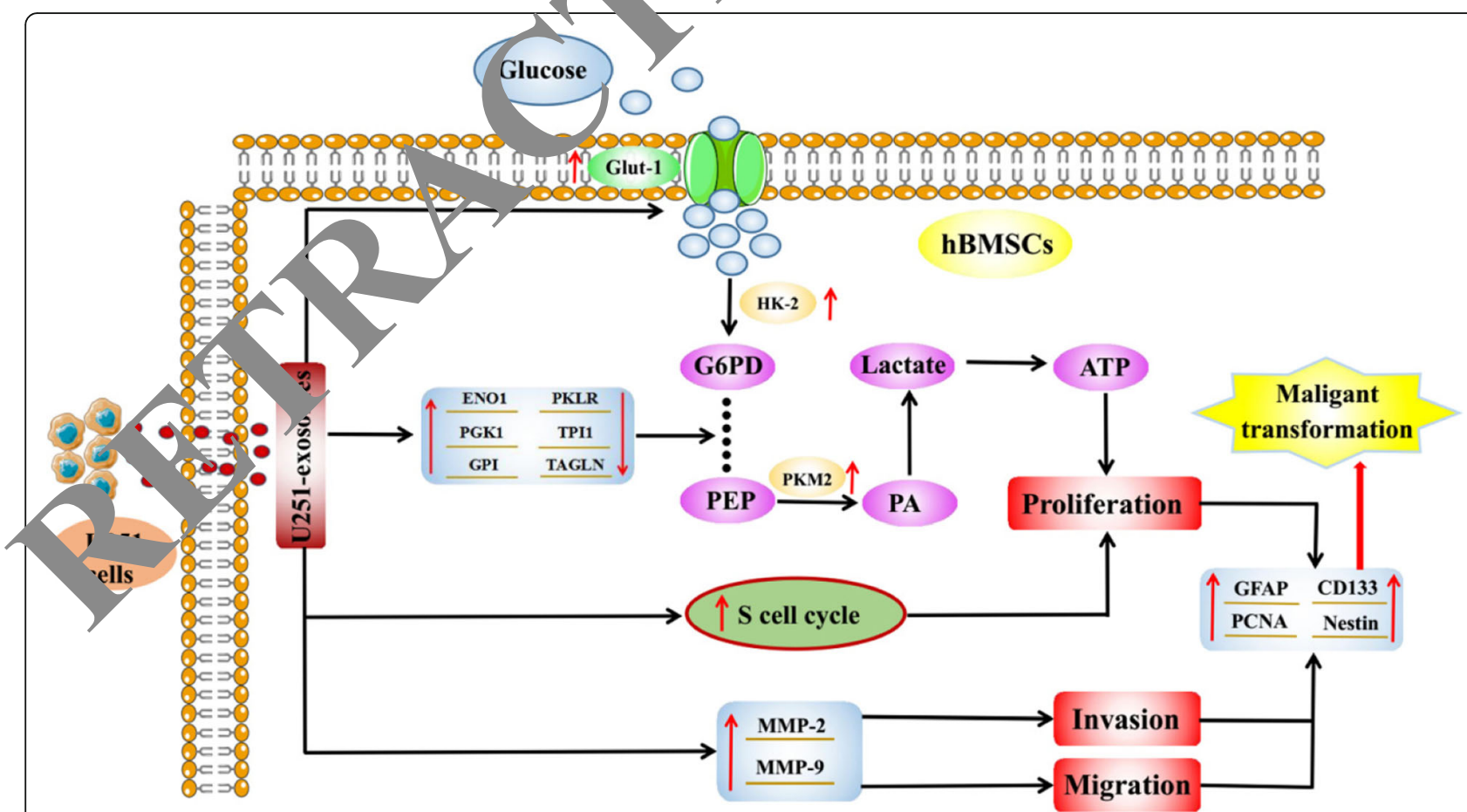

Fig. 13 Exosomes derived from glioma U251 cells induce a tumor-like phenotype by promoting cell proliferation, invasion, and migration and expressing tumor-associated proteins, possibly through activating the glycolytic pathway in human bone marrow mesenchymal cells 


\section{Abbreviations}

1, 3-BPG: 1, 3-Bisphosphoglycerate; 2-DE: Two-dimensional gel electrophoresis; 2-DG: 2-Deoxy-D-glucose; AKT: Protein kinase B; ANXA2: Annexin A2; CAFs: Cancer-associated fibroblasts; CCK-8: Cell Counting Kit-8; CSCs: Cancer stem cells; DAVID: Database for Annotation, Visualization, and Integrated Discovery; DMEM: Dulbecco's modified Eagles medium; ENO1: Alpha-enolase; FBS: Fetal bovine serum; GAPDH: Glyceraldehyde-3-phosphate dehydrogenase; GFAP: Glial fibrillary acidic protein; Glut-1: Glucose transporter type 1; hBMSCs: Human bone marrow mesenchymal stem cells; HK-2: Hexokinase-2; IEF: Isoelectric focusing; KEGG: Kyoto Encyclopedia of Genes and Genomes;

MSCs: Mesenchymal stem cells; OD: Optical density; PAGE: Polyacrylamide gel electrophoresis; PBS: Phosphate-buffered saline; PCNA: Proliferating cell nuclear antigen; PEP: Phosphoenolpyruvate; PI: Propidium iodide; PI3K: Phosphatidylinositol 3-kinase; PKLR: Pyruvate kinase PKLR; PKM2: Pyruvate Kinase M2; SDS: Sodium dodecyl sulfate; TAGLN: Transgelin; Tsg101: Tumor susceptibility gene 101 protein

\section{Acknowledgements}

The authors are grateful to Key Laboratory of Preclinical Research of New Drugs in Gansu Province of China.

\section{Funding}

This work was financially supported by the National Natural Science Foundation of China (81000878) and Natural Science Foundation of Gansu (1506RJZA231) and Fundamental Research Funds for the Central Universities of Lanzhou city (Izujbky-2017-126, Izujbky-2015-287) and Talent innovation and entrepreneurship science and technology projects of Lanzhou city (2014-RC-68) and Chengguan District Science and Technology Project of Lanzhou city (2016-7-6, 2016-7-8) and Natural Science Foundation of Gansu province (1506RJZA231).

\section{Availability of data and materials}

The datasets that support the conclusions are included within the arti

\section{Authors' contributions}

ZJM is the guarantor of integrity of the entire study and co experimental studies and manuscript preparation. XC con experimental studies. LL contributed to the manuscript) reparatio statistical analysis. GHC contributed to the experim contributed to the experimental studies and man ntal studies. YY man cript preparation. YH contributed to the analysis and interpretation of $\mathrm{d}$ YBL con ributed to the literature research. ZQC contributed to the data acqu nd literature research. YW contributed to the statistical acis. XXW Drafted the article and revised it critically. All authors read and apy the final manuscript.

Ethics approval and consen to $p$. icipate Not applicable

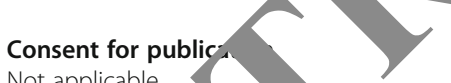
Not applicable

\section{Competin interests}

The authon ard they have no competing interests.

\section{bli har's Note}

Sp. er Nature remains neutral with regard to jurisdictional claims in publs maps and institutional affiliations.

\section{Author details}

${ }^{1}$ The Second Clinical Medical College, Lanzhou University, Lanzhou 730000, Gansu, China. ${ }^{2}$ The First Clinical Medical College, Lanzhou University, Lanzhou 730000, Gansu, China. ${ }^{3}$ School of Basic Medical Sciences, Lanzhou University, Lanzhou 730000, Gansu, China. ${ }^{4}$ Institute of Pharmacology, School of Basic Medical Science, Lanzhou University, Lanzhou 730000, Gansu, China. ${ }^{5}$ Key Laboratory of Preclinical Study for New Drugs of Gansu Province, Lanzhou 730000, Gansu, China. '5Chool of Basic Medical Sciences of Lanzhou University, School of Medicine, 205 Tianshui Rd South, Lanzhou 730000, Gansu, China.
Received: 4 September 2018 Revised: 23 December 2018 Accepted: 21 January 2019 Published online: 15 February 2019

\section{References}

1. Bovenberg MS, Degeling MH, Tannous BA. Advances in stem cell therapy against gliomas. Trends Mol Med. 2013;19(5):281-91.

2. Serakinci N, Fahrioglu U, Christensen R. Mesenchymal stem cells, ca ver challenges and new directions. Eur J Cancer. 2014;50(8):1522-30

3. Dvorak HF, Nagy JA, Dvorak AM. Structure of solid tumors an vasculature: implications for therapy with monoclonal antibodie Cells. 1991;3(3):77-85.

4. Dickson DJ, Shami PJ. Angiogenesis in acute and ch leukemid Le Leuk Lymphoma. 2001;42(5):847-53.

5. Hong IS, Lee HY, Kang KS. Mesenchymal ster cells and car firends or enemies? Mutat Res. 2014;768:98-106.

6. Orbay H, Tobita M, Mizuno H. Mesenchyma tem cells isplated from adipose and other tissues: basic bio icalpi ties an a clinical applications. Stem Cells Int. 20120012. 718.

7. Hill BS, Pelagalli A, Passaro N annetti A. oreducated mesenchymal stem cells promote pro-m at ic phenoty f. Oncotarget. 2017;8(42): 73296-311.

8. Mohammadpour H rathollah Nougoftar Zarif M, Shahbazfar AA Irradiation enhar es St eptibility of tumor cells to the antitumor effects of TNF-a activatea nos madmesenchymal stem cells in breast cancer model. Sci Rep. 20 28433.

9. Galipeaw Sensébé L. énchymal stromal cells: clinical challenges and therapeu artunities. Cell Stem Cell. 2018;22(6):824-33.

10. Yu FX, Hu WJ 10 Lheng YH, Zhang QY, Chen L. Bone marrow mesenchyr al stem cells promote osteosarcoma cell proliferation and invasion. Wo 'á J Surg Oncol. 2015;13:52.

11. ntie I, Ilmonen M, Alminaite A, Ozerdem U, Alitalo K, Salven P. $t$ bone marrow-derived cells recruited during angiogenesis prise precursors for periendothelial vascular mural cells. Blood. 04;104(7):2084-6.

Calvi LM, Link DC. The hematopoietic stem cell niche in homeostasis and disease. Blood. 2015;126(22):2443-51.

3. Liu J, Zhang Y, Bai L, Cui X, Zhu J. Rat bone marrow mesenchymal stem cells undergo malignant transformation via indirect co-cultured with tumour cells. Cell Biochem Funct. 2012;30(8):650-6.

14. Jeon ES, Moon HJ, Lee MJ, Song HY, Kim YM, Cho M, Suh DS, Yoon MS, Chang CL, Jung JS, Kim JH. Cancer-derived lysophosphatidic acid stimulates differentiation of human mesenchymal stem cells to myofibroblast-like cells. Stem Cells. 2008;26(3):789-97.

15. Ha D, Yang N, Nadithe V. Exosomes as therapeutic drug carriers and delivery vehicles across biological membranes: current perspectives and future challenges. Acta Pharm Sin B. 2016;6(4):287-96.

16. Kowal J, Tkach M, Théry C. Biogenesis and secretion of exosomes. Curr Opin Cell Biol. 2014:29:116-25.

17. Paggetti J, Haderk F, Seiffert M, Janji B, Distler U, Ammerlaan W, Kim YJ, Adam J, Lichter P, Solary E, Berchem G, Moussay E. Exosomes released by chronic lymphocytic leukemia cells induce the transition of stromal cells into cancer-associated fibroblasts. Blood. 2015;126(9):1106-17.

18. El-Saghir J, Nassar F, Tawil N, El-Sabban M. ATL-derived exosomes modulate mesenchymal stem cells: potential role in leukemia progression. Retrovirology. 2016;13(1):73.

19. Cheng Q, Li X, Liu J, Ye Q, Chen Y, Tan S, Liu J. Multiple myeloma-derived exosomes regulate the functions of mesenchymal stem cells partially via modulating miR-21 and miR-146a. Stem Cells Int. 2017;2017:9012152.

20. Li X, Wang S, Zhu R, Li H, Han Q, Zhao RC. Lung tumor exosomes induce a pro-inflammatory phenotype in mesenchymal stem cells via NFKB-TLR signaling pathway. J Hematol Oncol. 2016;9:42.

21. Ma ZJ, Wang XX, Su G, Yang JJ, Zhu YJ, Wu YW, Li J, Lu L, Zeng L, Pei HX. Proteomic analysis of apoptosis induction by lariciresinol in human HepG2 cells. Chem Biol Interact. 2016;256:209-19.

22. Ma ZJ, Lu L, Yang JJ, Wang XX, Su G, Wang ZL, Chen GH, Sun HM, Wang MY, Yang Y. Lariciresinol induces apoptosis in HepG2 cells via mitochondrial-mediated apoptosis pathway. Eur J Pharmacol. 2018;821:1-10.

23. Ma ZJ, Yan H, Wang YJ, Yang Y, Li XB, Shi AC, Jing-Wen X, Yu-Bao L, Li L, Wang XX. Proteomics analysis demonstrating rosmarinic acid suppresses cell growth by blocking the glycolytic pathway in human HepG2 cells. Biomed Pharmacother. 2018;105:334-49. 
24. Kahlert C, Kalluri R. Exosomes in tumor microenvironment influence cancer progression and metastasis. J Mol Med (Berl). 2013;91(4):431-7.

25. Lou G, Song X, Yang F, Wu S, Wang J, Chen Z, Liu Y. Exosomes derived from miR-122-modified adipose tissue-derived MSCs increase chemosensitivity of hepatocellular carcinoma. J Hematol Oncol. 2015; 8(1):122.

26. Studeny M, Marini FC, Dembinski JL, Zompetta C, Cabreira-Hansen M, Bekele BN, Champlin RE, Andreeff M. Mesenchymal stem cells: potential precursors for tumor stroma and targeted-delivery vehicles for anticancer agents. J Natl Cancer Inst. 2004;96(21):1593-603.

27. Kucerova L, Altanerova V, Matuskova M, Tyciakova S, Altaner C. Adipose tissue-derived human mesenchymal stem cells mediated prodrug cancer gene therapy. Cancer Res. 2007;67(13):6304-13.

28. Wang S, Li X, Xu M, Wang J, Zhao RC. Reduced adipogenesis after lung tumor exosomes priming in human mesenchymal stem cellsvia TGF $\beta$ signaling pathway. Mol Cell Biochem. 2017;435(1-2):59-66

29. Wang S, Xu M, Li X, Su X, Xiao X, Keating A, Zhao RC. Exosomes released by hepatocarcinoma cells endow adipocytes with tumor-promoting properties. J Hematol Oncol. 2018;11(1):82

30. Zhang YM, Zhang ZM, Guan QL, Liu YQ, Wu ZW, Li JT, Su Y, Yan CL, Luo YL, Qin J, Wang Q, Xie XD. Co-culture with lung cancer A549 cells promotes the proliferation and migration of mesenchymal stem cells derived from bone marrow. Exp Ther Med. 2017;14(4):2983-91.

31. Tan B, Shen L, Yang K, Huang D, Li X, Li Y, Zhao L, Chen J, Yi Q, Xu H, Tian J, Zhu J. C6 glioma-conditioned medium induces malignant transformation of mesenchymal stem cells: possible role of S100B/RAGE pathway. Biochem Biophys Res Commun. 2018:495(1):78-85.

32. Ning $X$, Zhang $H$, Wang $C$, Song $X$. Exosomes released by gastric cancer cells induce transition of pericytes into cancer-associated fibroblasts. Med Sci Monit. 2018:24:2350-9.

33. Chowdhury R, Webber JP, Gurney M, Mason MD, Tabi Z, Clayton A. Cance exosomes trigger mesenchymal stem cell differentiation into proangiogenic and pro-invasive myofibroblasts. Oncotarget. 2015;6(2):715-31.

34. Wang L, Kong W, Liu B, Zhang X. Proliferating cell nuclear antigen pronotes cell proliferation and tumorigenesis by up-regulatingSTAT3 in non lung cancer. Biomed Pharmacother. 2018;104:595-602.

35. Dejure FR, Eilers M. MYC and tumor metabolism: chicken an egg. EMB 2017;36(23):3409-20.

36. Kološa K, Motaln H, Herold-Mende C, Koršič M, Lah TT Paracrin "ects of mesenchymal stem cells induce senescence and glioblastoma stem-like cells. Cell Transplant. 201 24(4):631-44.

37. Zhang J, Liu L, Wang J, Ren B, Zhang L, Li W. FC Dononetin, In isoflavone from Astragalus membranaceus inhibits prolifera and m tastasis of ovarian cancer cells. J Ethnopharmacol 2018;221:9

38. Vinores SA, Marangos PJ, Bonnin JM, RU IJ Immunoradiometric and immunohistochemical demonstration of ey on écific enolase in experimental rat gliomas. Can 198 44(6):2595-9.

39. Zhang M, Song T, Yang I hen i Nu L, Y o jg Z, Fang J. Nestin and CD133: valuable stem cell-specific cermining clinical outcome of glioma patients. J F\&p C'in Cà Res. 2008;27:85.

40. Bradshaw A, Wir sekera A, To ST, Peng L, Davis PF, Itinteang T. Cancer stem cell hiera chy hlastorna multiforme. Front Surg. 2016;3:21.

41. Aizawa T segawa K, Mo T, Haga S, Ikeda K, Yoshikawa K. Neural stem $c$ 1-like gene expression in a mouse ependymoma cell line trarsti d hur an BK polyomavirus. Cancer Sci. 2011;102(1):122-9.

42. Delude ( norig -nesis: testing ground for cancer stem cells. Nature. 2011; 7377):S

vM Chang JW. Current status and issues in cancer stem cell study. ancenmiest. 2008:26(7):741-55.

44. San Y, Sun J, Wang Z, Zhou Y, G Y, Gu Y, Zhang H, Zhao H. Dit,erentially expressed and survival-related proteins of lung adenocarcinoma with bone metastasis. Cancer Med. 2018;7(4):1081-92.

45. Zhan P, Zhao S, Yan H, Yin C, Xiao Y, Wang Y, Ni R, Chen W, Wei G, Zhang P. a-Enolase promotes tumorigenesis and metastasis via regulating AMPK mTOR pathway in colorectal cancer. Mol Carcinog. 2017;56(5):1427-37.

46. Fu QF, Liu Y, Y F, Hua SN, Qu HY, Dong SW, Li RL, Zhao MY, Zhen Y, Yu XL, Chen YY, Luo RC, Li R, Li LB, Deng XJ, Fang WY, Liu Z, Song X. Alphaenolase promotes cell glycolysis, growth, migration, and invasion in nonsmall cell lung cancer through FAK-mediated PI3K/AKT pathway. J Hematol Oncol. 2015;8:22.
47. Benz J, Hofmann A. Annexins: from structure to function. Biol Chem. 1997 378(3-4):177-83

48. Deng L, Gao Y, Li X, Cai M, Wang H, Zhuang H, Tan M, Liu S, Hao Y, Lin B. Expression and clinical significance of annexin A2 and human epididymis protein 4 in endometrial carcinoma. J Exp Clin Cancer Res. 2015;34:96.

49. Wang CY, Lin CF. Annexin A2: its molecular regulation and cellular expression in cancer development. Dis Markers. 2014;2014:308976. https:// doi.org/10.1155/2014/308976.

50. Li X, Zheng Y, Lu Z. PGK1 is a new member of the protein kind Cycle. 2016;15(14):1803-4.

51. Guo S, Xiao Y, Li D, Jiang Q, Zhu L, Lin D, Jiang H, Chen W, Wang Fang W, Lin L. PGK1 and GRP78 overexpression correl tes with clinic significance and poor prognosis in Chinese endome sancer pa Oncotarget. 2017;9(1):680-90.

52. Yan H, Yang K, Xiao H, Zou YJ, Zhang WB, L. HY. Over-exp. on of cofilin1 and phosphoglycerate kinase 1 in astroc mas involved $i n$ pathogenesis of radioresistance. CNS Neurosci Ther 2012 9):729-36

53. Ariosa AR, Klionsky DJ. A novel rolen glya cnway kinase in regulating autophagy has impli cons ancer therapy. Autophagy. 2017; 13(7):1091-2.

54. Madonna R, Görbe A, Fer inà D, De Caten ına R. Glucose metabolism, hyperosmotic stress, and reprogr a ing of somatic cells. Mol Biotechnol. 2013;55(2):169-78.

55. Tekade RK, Sun The arburg effect and glucose-derived cancer theranostics. Dru, 2017;22(11):1637-53.

56. Fu Y, Liu S, Yin S, Ni Xiong W, Tan M, Li G, Zhou M. The reverse Warburd ffect is likely be an Achilles' heel of cancer that can be exploited run therapy. Oncotarget. 2017;8(34):57813-25.

57. Xu Q, Zhal a Q, Isi, da Y, Hajjar S, Tang X, Shi H, Dang CV, Le AD. EGF induces ep helial-mesenchymal transition and cancer stem-like cell roperties in numan oral cancer cells via promoting Warburg effect. target. 2017;8(6):9557-71.

Bo iccelli G, Avnet S, Grisendi G, Salerno M, Granchi D, Dominici M, Ku uzaki K, Baldini N. Role of mesenchymal stem cells in osteosarcoma and netabolic reprogramming of tumor cells. Oncotarget. 2014;5(17):7575-88. Tasselli L, Chua KF. Cancer: metabolism in 'the driver's seat. Nature. 2012; 492(7429):362-3

60. Zhang X, Wu D, Aldarouish M, Yin X, Li C, Wang C. ETS-1: a potential target of glycolysis for metabolic therapy by regulating glucose metabolism in pancreatic cancer. Int J Oncol. 2017;50(1):232-40.

61. Wolf A, Agnihotri S, Micallef J, Mukherjee J, Sabha N, Cairns R, Hawkins C, Guha A. Hexokinase 2 is a key mediator of aerobic glycolysis and promotes tumor growth in human glioblastoma multiforme. J Exp Med. 2011;208(2): 313-26.

62. Yu C, Hu ZQ, Peng RY. Effects and mechanisms of a microcurrent dressing on skin wound healing: a review. Mil Med Res. 2014;1:24.

63. Christofk HR, Vander Heiden MG, Harris MH, Ramanathan A, Gerszten RE, Wei R, Fleming MD, Schreiber SL, Cantley LC. The M2 splice isoform of pyruvate kinase is important for cancer metabolism and tumour growth. Nature. 2008:452(7184):230-3.

Ready to submit your research? Choose BMC and benefit from:

- fast, convenient online submission

- thorough peer review by experienced researchers in your field

- rapid publication on acceptance

- support for research data, including large and complex data types

- gold Open Access which fosters wider collaboration and increased citations

- maximum visibility for your research: over $100 \mathrm{M}$ website views per year

At BMC, research is always in progress.

Learn more biomedcentral.com/submission 